\title{
Impacts of climatic anomalies on provisioning strategies of a Southern Ocean predator
}

\author{
Mary-Anne Lea ${ }^{1,2, *}$, Christophe Guinet ${ }^{2}$, Yves Cherel ${ }^{2}$, Guy Duhamel ${ }^{3}$, \\ Laurent Dubroca ${ }^{2}$, Patrice Pruvost ${ }^{3}$, Mark Hindell ${ }^{1}$ \\ ${ }^{1}$ Antarctic Wildlife Research Unit, School of Zoology, University of Tasmania, PO Box 252-05, Hobart, Tasmania 7001, Australia \\ ${ }^{2}$ Centre d'Etudes Biologiques de Chizé UPR 1934 du-CNRS, 79360 Villiers-en-Bois, France \\ ${ }^{3}$ Muséum National d'Histoire Naturelle, Département des Milieux et Peuplements Aquatiques, \\ Biodiversité et Dynamique des Communautés Aquatiques USM 403, case postale 2643 rue Cuvier, 75005 Paris, France
}

\begin{abstract}
The large temporal and spatial variability in marine productivity encountered by marine predators may negatively influence breeding success. The Antarctic fur seal Arctocephalus gazella (AFS), a marine predator in the Southern Ocean (SO) ecosystem with a circumpolar distribution, exhibits a short, 4 mo lactation coinciding with increased summer marine productivity. The diet of AFS, and the distance to significant and productive oceanographic features, such as the Antarctic Polar Frontal Zone (PFZ), varies considerably between populations. We studied the foraging activity, foraging efficiency and the pup provisioning strategies of lactating AFS at a key breeding site in the southern Indian Ocean, the Kerguelen Archipelago. Foraging parameters were examined in relation to interannual variability in oceanographic conditions and prey availability in the PFZ over 3 consecutive breeding seasons (1998 to 2000). The location of foraging zones, diving activity, diet and foraging efficiency varied significantly between years, concurrently with annual changes in seasurface temperature (SST) and prey availability. The strongest recorded El Niño Southern Oscillation event in 1997-1998 coincided with anomalously warm waters in the vicinity of the Archipelago. Deeper diving by females, reduced maternal and pup body condition, and minimal pup growth rates and low catch per unit effort of the primary prey species, lanternfishes (Myctophidae) were all recorded in this period. Maternal size was positively related to the growth performance of pups only in this period, indicating the importance of age/size and/or experience in mediating environmental fluctuations. Foraging efficiency over a foraging cycle and variability in mean provisioning rates (trip duration), were identified as proxies of prey availability within the foraging range of seals, emphasising the effectiveness of the use of AFS foraging behaviour as an indicator of both food and oceanographic variability and climatic anomalies. The increasing frequency of anomalously warm SST events in sectors of the SO, however, may elicit specific behavioural responses from 'central place foragers' (i.e. species that return to breeding sites to feed their young) to avoid sustained poor body condition of females and their weaned offspring.
\end{abstract}

KEY WORDS: Antarctic fur seal · Polar Front · Pinniped · ENSO - Foraging · Growth · Diving · Seabird $\cdot$ Myctophid $\cdot$ Maternal care

Resale or republication not permitted without written consent of the publisher

\section{INTRODUCTION}

Marine productivity is influenced on large scales by seasonal changes in temperature (Moore \& Abbott 2000) and the supply of trace elements such as iron (Blain et al. 2001), and may also be enhanced by oceanographic structures such as frontal systems
(Abbott et al. 2000), current boundaries (Tynan 1998) and eddies (Williams \& Follows 1998). Not surprisingly, fishes (Block et al. 1997) and other marine predators (Springer et al. 1996, Field et al. 2001) show environmental preferences that are linked to regions of productivity and, by inference, foraging success. The marine environment is however highly dynamic, and 
large scale changes such as regime shifts (Hare \& Mantua 2000, Weimerskirch et al. 2003) may considerably alter environmental variables and prey structure over long time scales (years to decades). Alternatively, climatic phenomena such as El Niño Southern Oscillation (ENSO) events may produce anomalous environmental conditions that drastically change marine productivity in the short-term (months to years) (Fiedler 2002). Therefore, the mobility of predator species may largely determine the extent to which anomalous climatic conditions and the movement of productive frontal and upwelling zones affect their foraging patterns and reproductive success.

Otariids (fur seals and sea lions), a widely distributed group of pinnipeds that extend from polar to equatorial regions (Gentry \& Kooyman 1986), combine foraging activity with the raising of their single offspring by interspersing periods of foraging at sea with periods ashore (termed 'income breeders'; Stearns 1992). Consequently they may be less well buffered against environmental variability than their larger counterparts, phocid seals (Boyd 2000), which separate feeding and breeding. Returning regularly to breeding sites in order to feed their young, otariids are defined as 'central place foragers' (Orians \& Pearson 1979). As such, the maximum foraging range attainable during feeding trips and the maximum time allocated to foraging are constrained by the physiological demands of the pup. Mothers should optimise the time allocated to various activities in order to maximise the rate of food delivery to young under all conditions (Boyd 1999). However, in years where environmental perturbations affect prey availability and the ability of otariid mothers to locate prey during lactation, catastrophic repercussions for breeding success can occur, with up to nearly $100 \%$ pup mortality (Trillmich \& Dellinger 1991, Boyd et al. 1995, Soto et al. 2004).

Lactation is one of the more energetically expensive phases of a female mammal's life (Oftedal 1984). Relative to maintenance costs, the provisioning of milk to ensure offspring growth is costly (Lee et al. 1991). While suckling, a mother makes many decisions concerning the allocation of time for foraging to meet her own energetic requirements, and for nursing her young. Such choices may vary in relation to food availability, maternal age, size and experience and age of offspring (Georges \& Guinet 2000, Beauplet et al. 2004). For a given species and different populations within the same species, where the availability of food is variable both spatially and temporally, these decisions may be crucial, affecting current and possibly future reproductive success, and in extreme instances even maternal survival (Trites 1991, Lunn \& Boyd 1993b).

The Antarctic fur seal (AFS) is a tractable model for examining the relationship between environmentally induced fluctuations in prey availability, foraging behaviour and subsequent breeding success. Its breeding distribution is circumpolar, including the majority of sub-Antarctic islands spanning the Southern Ocean (SO) from Marion Island $\left(46^{\circ} 54^{\prime} \mathrm{S}, 37^{\circ} 45^{\prime} \mathrm{E}\right)$ to the Antarctic Peninsula $\left(62^{\circ} 29^{\prime} \mathrm{S}, 60^{\circ} 47^{\prime} \mathrm{W}\right)$. Across this distribution, hydrographic features, climatic conditions and prey species composition vary considerably (Tynan 1998, Moore et al. 1999). Variability in the marine environment during the brief lactation period may translate to longer search times and reduced provisioning and growth rates for young, as has been observed at South Georgia (Atlantic sector of SO) where AFS primarily feed on Antarctic krill Euphausia superba (Lunn \& Boyd 1993b, Boyd et al. 1994).

In the southern Indian Ocean, AFS feed primarily on myctophids, a family of nocturnally surface migrating mesopelagic fishes, that are rich in energy and highly abundant in the Antarctic Polar Frontal Zone (Cherel et al. 1997, Klages \& Bester 1998, Duhamel et al. 2000, Lea et al. 2002b, 2003). Movements of the Antarctic Polar Front (PF) by 1 to $2^{\circ}$ north or south occur interannually in this sector of the SO (Moore et al. 1999), potentially affecting the abundance of prey within the foraging range of AFS. One of the main objectives of a 3 yr multidisciplinary study examining the myctophid predator-prey relationship at Îles Kerguelen, was to determine whether the foraging behaviour and consequent energy acquisition of female AFS was responsive to changes in environmental conditions and subsequent marine productivity and, if such changes were evident, to discover whether increased costs of foraging translated directly to the pup in terms of reduced provisioning rates, or whether females were able to compensate by increasing the quality and/or quantity of resources per suckling event (Trillmich \& Lechner 1986, Hofer \& East 1993). Such studies (e.g. Post \& Stenseth 1999) are few for large mammals, particularly marine species.

We aimed to describe the at-sea distribution and foraging effort of lactating AFS over 3 consecutive years in the context of changing oceanography and prey availability in the Antarctic Polar Frontal Zone (PFZ). Dietary preferences, provisioning rates, indices of foraging efficiency and subsequent growth rates of pups were compared between years and examined in relation to maternal and environmental parameters (chlorophyll a concentration, sea-surface temperature and bathymetric features).

\section{MATERIALS AND METHODS}

The study was conducted at Cap Noir $\left(49^{\circ} 07^{\prime} \mathrm{S}\right.$, $70^{\circ} 45^{\prime} \mathrm{E}$ ) on a mainland colony of 750 to 800 AFS (Guinet et al. 2001) in the Kerguelen Archipelago. 
These islands support an increasing population of AFS, most recently estimated at $>10000$ seals (Guinet et al. 1996). The foraging behaviour of lactating adult female fur seals and the allocation of resources to the pup (body condition, growth and daily mass gain), were studied during the 1998 (February to March 1998), 1999 (November 1998 to March 1999) and 2000 (December 1999 to March 2000) austral breeding seasons. Interannual comparisons correspond to the period from 20 January to early March.

Oceanographic context and environmental data. The Antarctic Circumpolar Current (ACC: Orsi et al. 1995) comprises 3 fronts: (1) the Sub-tropical Front (STF); (2) the Sub-Antarctic Front (SAF) and (3) the Polar Front (PF). Kerguelen is in the immediate vicinity of the $\mathrm{PF}$, which passes within 2 to $3^{\circ}$ latitude to the north (Sparrow \& Heywood 1996), and occasionally to the south (Moore et al. 1999) of the Archipelago. The Polar Frontal Zone (PFZ), bounded by the SAF to the north and the PF to the south (Belkin \& Gordon 1996), encompasses the Kerguelen Archipelago and is an area of elevated nutrients (Bucciarelli et al. 2001) and high primary and secondary productivity (Duhamel et al. 2000, Moore \& Abbott 2000, Blain et al. 2001).

Bathymetric data at the foraging locations of seals (see following subsection) were extracted from the ETOPO5 database $\left(5^{\prime} \times 5^{\prime}\right.$ resolution). Weekly mean seasurface temperatures (MCSST) $\left({ }^{\circ} \mathrm{C}\right)$ and monthly chlorophyll a concentrations $\left(\mathrm{mg} \mathrm{m}^{-3}\right)$ data from the PODAAC (Physical Oceanography Distributed Active Archive Center) (ftp://podaac.jpl.nasa.gov/pub/sea_surface_ temperature/avhrr/mcsst/) and SeaWIFS respectively, were extracted for an area $(750 \mathrm{~km}$ radius of Cap Noir, Lea \& Dubroca 2003) encompassing the maximum foraging range of AFS. Monthly SST anomaly data (SSTA) was estimated from blended ship, buoy and bias-corrected satellite data (Reynolds \& Smith 1994) from 1991 to 2002, extracted from the National Centers for Environmental Prediction (NCEP) Reynolds analyses (http:// iridl.ldeo.columbia.edu/SOURCES/.NOAA/.NCEP/ .EMC/.CMB/.GLOBAL/Reyn_SmithOIv1/.weekly/.ssta/). Weekly data $\left(1^{\circ}\right.$ grid) were obtained for the region bounded by $46.5^{\circ} \mathrm{S}, 69.5^{\circ} \mathrm{E}$ and $52.5^{\circ} \mathrm{S}, 75.5^{\circ} \mathrm{E}$.

Maternal energy acquisition. Maternal attendance behaviour, the at-sea distribution and diving activity, dietary preferences, indices of prey availability and body condition of female AFS were measured as proxies for rates of maternal energy acquisition.

Attendance patterns: The presence/absence of 20 lactating females with VHF transmitters was monitored in each year. A DCCII VHF receiving station and antenna (ATS) located within the colony scanned frequencies for $30 \mathrm{~s}$ every $10 \mathrm{~min}$ (see Bonadonna et al. [2000] and Lea et al. [2002c] for detailed description of capture and device attachment methods). Back- mounted VHF transmitters with external whip antennae $(50 \times 30 \times 15 \mathrm{~mm}, 25 \mathrm{~g}$, Sirtrack) were used in preference to flipper mounted tags (VHF transmitter with internal loop antennae mounted on Dalton Roto tags: $35 \times 25 \times 15$ mm, 26.3 g; Dalton Supplies), which created drag and damaged newly tagged fore-flippers. Data were downloaded from the receiving station to a laptop computer every $5 \mathrm{~d}$. Shore bout (SB) and foraging trip (FTD) durations were calculated by manually screening the data for the seals' arrival and departure times. After the removal of individuals that had either lost pups $(\mathrm{n}=3$ ) or whose tags had failed $(\mathrm{n}=2)$, data for 20, 19 and 16 mother-pup pairs were available in 1998, 1999 and 2000 respectively.

At-sea distribution and foraging activity: Time-depth recorders (TDR, Wildlife Computers) mounted on platform terminal transmitters (ST-10 PTT, Telonics) were used to monitor the spatial distribution patterns (see Bonadonna et al. 2000) of 11 (1998), 11 (1999) and 10 (2000) lactating AFS. Packages were hydrodynamically shaped to reduce drag and were attached by plastic cables ties to a nylon-webbing strap glued dorsally to the midline of the fur seal between the scapulae. AFS were marked with a number on their hind-quarters with peroxide hair-dye (Bristol MyersSquibb) and released with their pup. The colony was checked at least twice daily (08:00 and 18:00 h) for the return of marked females.

The TDRs recorded depth $( \pm 1 \mathrm{~m})$ every $5 \mathrm{~s}$ during single foraging trips (FT). Temperature $\left( \pm 0.1^{\circ} \mathrm{C}\right)$ was recorded every 5 s by all Mark 7 TDRs in 1999 and 2000. In 1998, the data capacity of 3 Mark 5 TDRs ( $n=6$ of 11 deployments) was insufficient for the long duration of trips, and temperature was sampled each $5 \mathrm{~s}(\mathrm{n}=2), 30 \mathrm{~s}(\mathrm{n}=3)$, $60 \mathrm{~s}(\mathrm{n}=5)$ or $300 \mathrm{~s}(\mathrm{n}=1)$. Mean nightly SST was calculated from TDR temperature records (Lea \& Dubroca 2003). TDR data were corrected for surface drift and dives $\geq 4 \mathrm{~m}$ were extracted (Lea et al. 2002c). The diving effort of AFS was assessed in 2 ways: (1) as proportional time spent diving (TSD) per trip and per night (see Lea et al. 2002c) and (2) as diving rate measured as the mean daily vertical distance attained per AFS during a foraging trip. The length of the TDR record was used in cases where the TDR memory was full prior to the female returning (see Table 1). Dive rate was calculated as $\sum$ (max. dive depth $\times 2$ )/FTD, with maximum dive depth in meters and FTD in days. Other dive parameters such as mean dive depth were also calculated (Lea et al. 2002c). The spatial distribution of diving activity was then calculated for each year using custom-made software (Laurent Dubroca, CEBC-CNRS), which attributed time spent diving (TSD) per foraging trip recorded by TDR to a particular foraging location indicated by the PTT derived locations (Guinet et al. 2001). Analyses were limited to ARGOS locations of Accuracy Classes 0 to 3 
(Bonadonna et al. 2000). The TSD per $0.1^{\circ} \times 0.1^{\circ}(11.1 \mathrm{~km}$ latitude $\times 7.3 \mathrm{~km}$ longitude) grid cell encompassing the foraging zones of seals was calculated and mapped using ArcView GIS software (ESRI: Guinet et al. 2001).

AFS diet and prey availability: The diet of female Antarctic fur seals breeding at Cap Noir, Îles Kerguelen, was examined during February 1998, 1999 and 2000 from the analysis of fresh faecal samples from areas used by lactating females (see Lea et al. 2002b, 2003). The main prey of AFS at îles Kerguelen, mesopelagic myctophids (Cherel et al. 1997, Lea et al. 2002b, 2003), generally migrate to surface waters at night from daytime depths often in excess of $100 \mathrm{~m}$ (Duhamel et al. 2000). Pelagic fish trawls were conducted in the foraging zones determined by concurrent satellite telemetry of fur seals (Fig. 1) in 1998 and 1999 by the RV 'La Curieuse'. Transect sampling was conducted at night (21:00 to 04:00 h) at $50 \mathrm{~m}$ depth, which approximated the mean dive depth of fur seals initially recorded in February 1998 (Lea et al. 2002c): 5 sampling stations separated by $\sim 0.30^{\circ}$ longitude (15 $\mathrm{n}$ miles), were located along 4 zonal transects, separated by $0.40^{\circ}$ latitude (30 nautical miles) between $48.2^{\circ} \mathrm{S}$, $70.80^{\circ} \mathrm{E}$ and $49.40^{\circ} \mathrm{S}, 72.00^{\circ} \mathrm{E}$ (Fig. 1). Stationary sampling to $150 \mathrm{~m}$ (surface, 50 and $150 \mathrm{~m}$ ) was also conducted at several sites in 1998 and 1999, with 28 stations sampled in both years. The full transect was not surveyed in 2000 and was consequently excluded from analyses. The 30 min trawls ( 3 knots) were conducted using an 'international young gadoid pelagic trawl' (IYGPT) of $10 \mathrm{~mm}$ mesh size. Specimens were frozen on board and subsequently identified to species and measured at the research station (standard length and body mass). Catch per unit effort (CPUE: number of fishes caught $\mathrm{h}^{-1}$ ) was calculated for all fish species sampled in 1998 and 1999.

Maternal body condition: A sample of mothers with pups tagged for longitudinal growth studies (see following subsections), were measured and weighed during shore attendance bouts between 9 February and 12 March in each of the $3 \mathrm{yr}$. Body condition was estimated by an index (BCI) used by Guinet et al. (1998b) to remove the correlation between body mass and length. Body mass was regressed against standard length by pooling females from all years, and residual values were calculated. The residual values for each seal were compared between years by 1-way ANOVA. Positive residuals represented females heavier than average for individuals of that body length.
Maternal allocation and pup provisioning. Foraging efficiency: The mass gained by a pup during a foraging cycle $(\mathrm{FC}[\mathrm{d}]=\mathrm{FTD}+\mathrm{SB})$ is a relatively easily obtainable measure of maternal energy transfer to the pup (Guinet et al. 1999, 2000, Georges \& Guinet 2000). The pups of females equipped with PTTs were weighed each day during the fasting period of 1 maternal FTD, just before the arrival of the female and again immediately after her departure, to estimate the mass gained by the pup during the FC. When body mass was not recorded prior to the arrival of the female, it was estimated by linear regression of pup mass over time during the previous fasting bout.

Pup growth and body condition: Pup growth, was estimated by serial weighing and measurement of pups every 6 to $10 \mathrm{~d}$. In 1998 a random sample of 110 pups was selected in early February. In 1999 and 2000 pups were weighed, sexed and marked at or near birth ( 0 to $1 \mathrm{~d}$ old) and tracked throughout the lactation period. At $\sim 30 \mathrm{~d}$ (60 d in 1998) of age, pups were tagged in the trailing edge of each fore flipper (Size 1 Supertags, Dalton Supplies UK). Tags were removed at the end of the study. Growth rates $\left(\mathrm{g} \mathrm{d}^{-1}\right)$ were calculated individually by the linear regression of pup mass over time (4 to 6 weight measurements) for the $45 \mathrm{~d}$ period, from 30 January to 15 March. At the commencement of this period the pups were approximately 40 to $70 \mathrm{~d}$ old and many had started to moult. Sex and year comparisons of mean growth rates were conducted on log transformed data by 2-way ANOVA.

The body mass, length and body condition index (BCI) of pups, calculated as the residuals of pup body mass against standard length during the first week of March, were compared by 2-way ANOVA to determine any sex and year effects. The body condition of a

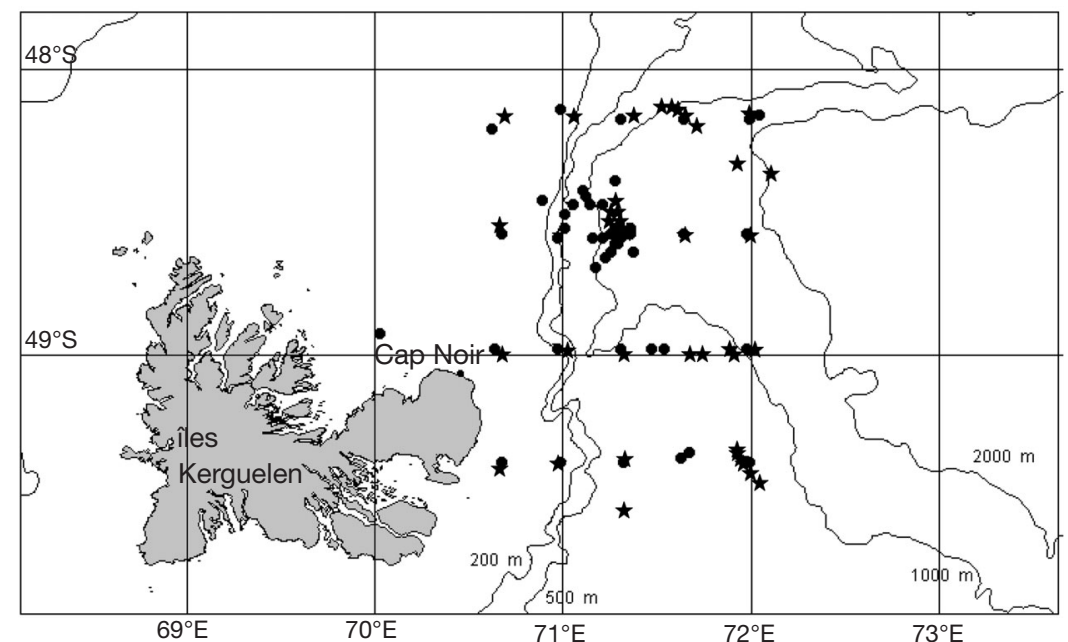

Fig. 1. Fish transect-survey trawl stations in $(\bullet) 1998$ and $(\star) 1999$ in Antarctic fur seal Arctocephalus gazella foraging zone to NE of the Kerguelen Archipelago 
different sample of pups was also estimated in February 1998, 1999 and 2000 by isotopic dilution of tritiated water. The experimental isotopic dilution procedure conducted during the study is described in Lea et al. (2002a). All mean values are reported \pm 1 SE of the mean unless otherwise stated, and statistical analyses were performed using SYSTAT Statistical Software (SPSS statistical package 1998).

\section{RESULTS}

\section{Environmental conditions}

Surface chlorophyll a plumes of high concentrations were evident to the NE of the archipelago in 1998, whilst concentrations were highest in the $\mathrm{SE}$, in 1999, with a NE and south east component in 2000 (Fig. 2). Chl a concentrations and MCSST values within the foraging range of fur seals from the Cap Noir colony were compared between years (Fig. 3). Elevated levels of chl a $\left(0.292 \mathrm{mg} \mathrm{m}^{-3}\right)$ occurred simultaneously with reduced mean sea-surface temperature, SST $\left(6.4^{\circ} \mathrm{C}\right)$ in February 2000. Chl a concentrations were similar in 1998 and 1999; however, warmer SSTs were observed in 1998 in than in to 1999 and 2000 (Fig. 3).

Maternal energy acquisition. Foraging distribution. Satellite tracks with concurrent dive profiles were recorded for 32 seals during the $3 \mathrm{yr}$ (Fig. 2). Foraging activity was generally distributed from the NE to the SE of Cap Noir, and was often concentrated in a zone on the edge of the Kerguelen Plateau approximately 60 to $70 \mathrm{~km} \mathrm{NE}$ of the colony. The maximum distance travelled from the colony in February during a foraging trip (68 to $547 \mathrm{~km}$ ) was highly positively correlated with FTD $\left(\mathrm{r}_{28}=0.905\right.$, $\mathrm{p}<0.001)$. AFS foraged closer to the colony in 1998 ( $82 \%<150 \mathrm{~km}, \mathrm{n}=11$; with the exception of 1 female) (Tables 1 \& 2) than in $1999(75 \%<150 \mathrm{~km}, \mathrm{n}=8)$ or $2000(22 \%<150 \mathrm{~km}, \mathrm{n}=9)$. The median foraging range of seals in each of the 3 yr was 111, 113 and $215 \mathrm{~km}$, respectively.

Table 1. Arctocephalus gazella. Maternal characteristics, foraging parameters, and pup mass gain rates of Antarctic fur seals fitted with satellite tags at Îles Kerguelen in 1998 to 2000 (M: male; F: female). BDG: behavioural dive group (see Lea et al. 2002c); FTD: foraging trip duration; $\mathrm{SST}_{\mathrm{TDR}}$ : time-depth recorder measure of sea surface temperature (see Lea \& Dubroca 2003); PMG: pup mass gain. Deployment types for 1998: PTT5, satellite platform terminal transmitter + Mark 5 Wildlife Computers TDR; for 1999, 2000: PTT7, satellite platform terminal transmitter + Mark 7 TDR. -: no data

\begin{tabular}{|c|c|c|c|c|c|c|c|c|c|}
\hline & Seal & BDG & $\begin{array}{l}\text { Length } \\
\text { (cm) }\end{array}$ & $\begin{array}{l}\text { Condition } \\
\left(\mathrm{kg} \mathrm{cm}^{-1}\right)\end{array}$ & $\begin{array}{l}\text { FTD } \\
\text { (d) }\end{array}$ & $\begin{array}{c}\text { Nightly } \\
\mathrm{SST}_{\mathrm{TDR}} \\
\left({ }^{\circ} \mathrm{C}\right)\end{array}$ & $\begin{array}{l}\text { Max. } \\
\text { distance } \\
(\mathrm{km})\end{array}$ & $\begin{array}{l}\text { Pup } \\
\text { sex }\end{array}$ & $\begin{array}{c}\text { Absolute } \\
\text { PMG } \\
\text { (kg) }\end{array}$ \\
\hline \multirow[t]{11}{*}{1998} & $0^{\mathrm{a}}$ & 1 & 117.0 & 0.232 & 7.41 & $4.6-4.9$ & 98 & M & 2.00 \\
\hline & 1 & 1 & 121.0 & 0.269 & 5.72 & $4.6-5.7$ & 97 & $\mathrm{~F}$ & - \\
\hline & $2^{\mathrm{a}}$ & 1 & 112.0 & 0.283 & 8.09 & $4.2-4.6$ & 152 & M & 1.65 \\
\hline & 3 & 1 & 115.0 & 0.212 & 2.96 & $4.5-4.6$ & 88 & M & 0.90 \\
\hline & $42^{\mathrm{a}}$ & 3 & 119.5 & 0.273 & 16.52 & $4.6-7.1$ & 547 & F & 3.60 \\
\hline & $43^{\mathrm{a}}$ & 1 & 117.5 & 0.260 & 4.95 & 4.8 & 111 & F & 1.00 \\
\hline & $47^{\mathrm{a}}$ & 4 & 119.0 & 0.280 & 8.39 & $4.2-4.9$ & 243 & M & - \\
\hline & 51 & 1 & 119.5 & 0.295 & 3.85 & $4.7-5.4$ & 68 & M & - \\
\hline & $52^{\mathrm{a}}$ & 1 & 112.0 & 0.262 & 6.77 & $4.5-4.7$ & 118 & M & 1.00 \\
\hline & 55 & 1 & 120.5 & 0.276 & 6.97 & $4.4-5.1$ & 145 & $\mathrm{~F}$ & - \\
\hline & 57 & 1 & 126.0 & 0.273 & 5.91 & $4.7-5.1$ & 93 & M & 1.44 \\
\hline \multirow[t]{11}{*}{1999} & 1 & 1 & 117.8 & 0.284 & 7.09 & $3.8-5.1$ & 190 & $\mathrm{M}$ & 1.24 \\
\hline & 55 & 1 & 121.5 & 0.271 & 6.45 & $4.6-6.1$ & 144 & $\mathrm{~F}$ & - \\
\hline & 57 & 1 & 116.1 & 0.309 & 4.03 & $4.5-5.2$ & 98 & F & - \\
\hline & L1 & 1 & 120.3 & 0.311 & 4.22 & $4.1-4.3$ & 86 & $\mathrm{~F}$ & 1.58 \\
\hline & L2 & 2 & 115.0 & 0.292 & 6.12 & $4.2-5.2$ & - & F & 2.56 \\
\hline & L3 & 2 & 125.0 & 0.297 & 10.03 & $3.1-4.3$ & 308 & M & 3.46 \\
\hline & L4 & 2 & 121.5 & 0.320 & 4.91 & $4.4-5.1$ & 123 & $\mathrm{~F}$ & - \\
\hline & L5 & 1 & 120.0 & 0.245 & 7.15 & $4.2-4.4$ & - & M & - \\
\hline & L7 & 3 & 118.3 & 0.258 & 15.87 & $4.6-7.3$ & - & $\mathrm{M}$ & - \\
\hline & L8 & 1 & 118.5 & 0.319 & 4.99 & $4.8-5.5$ & 103 & M & 2.24 \\
\hline & L9 & 2 & 115.7 & 0.270 & 9.13 & $4.5-5.4$ & 95 & F & - \\
\hline \multirow[t]{10}{*}{2000} & H3 & 3 & 114.5 & 0.304 & 12.26 & $3.7-6.5$ & 448 & $\mathrm{~F}$ & 3.84 \\
\hline & $\mathrm{H} 4$ & 1 & 113.0 & 0.260 & 8.91 & $4.4-5.5$ & 193 & M & 2.47 \\
\hline & H5 & 1 & 110.0 & 0.270 & 6.17 & $3.9-4.5$ & 186 & $\mathrm{~F}$ & - \\
\hline & H6 & 2 & 117.0 & 0.289 & 9.31 & $3.5-4.4$ & 259 & M & 2.94 \\
\hline & $\mathrm{H} 7$ & 2 & 115.0 & 0.246 & 8.82 & $3.6-4.2$ & 251 & $\mathrm{~F}$ & 2.62 \\
\hline & H8 & 1 & 119.3 & 0.264 & 5.16 & $4.5-4.8$ & 114 & M & 2.06 \\
\hline & S1 & 2 & 112.0 & 0.300 & 9.10 & $3.9-4.4$ & 215 & M & - \\
\hline & $\mathrm{S} 2$ & 1 & 117.3 & 0.270 & 3.98 & $4.6-4.7$ & - & $\mathrm{F}$ & 0.65 \\
\hline & S3 & 1 & 117.0 & 0.265 & 5.98 & $4.7-5.1$ & 81 & F & 1.38 \\
\hline & $\mathrm{S} 4$ & 2 & 112.5 & 0.294 & 10.37 & $3.6-5.5$ & 328 & $\mathrm{~F}$ & 3.78 \\
\hline
\end{tabular}

Table 2. Arctocephalus gazella. Summary statistics for females equipped with time-depth recorder/satellite (TDR/PTT) packages in 1998 to 2000; SE in round brackets, median maximum distance travelled in square brackets. Abbreviations as in Table 1

\begin{tabular}{|c|c|c|c|c|c|c|c|}
\hline Year & $\mathrm{n}$ & $\begin{array}{l}\text { Length } \\
\text { (cm) }\end{array}$ & $\begin{array}{l}\text { Condition } \\
\left(\mathrm{kg} \mathrm{cm}^{-1}\right)\end{array}$ & $\begin{array}{l}\text { FTD } \\
\text { (d) }\end{array}$ & $\underset{\left({ }^{\circ} \mathrm{C}\right)}{\text { Nightly } \mathrm{SST}_{\mathrm{TDR}}}$ & $\begin{array}{l}\text { Range } \\
(\mathrm{km})\end{array}$ & $\begin{array}{l}\text { Absolute } \\
\text { PMG (kg) }\end{array}$ \\
\hline 1998 mean & 11 & $118.1(1.2)$ & $0.265(0.007)$ & $7.0(1.1)$ & $4.2-7.1$ & 160 [111] & $1.66(0.36)$ \\
\hline 1999 mean & 11 & 119.1 (1.9) & $0.289(0.008)$ & $7.3(1.0)$ & $3.1-6.1$ & 143 [113] & $2.22(0.39)$ \\
\hline 2000 mean & 10 & $114.8(0.9)$ & $0.276(0.006)$ & $8.0(0.8)$ & $3.5-6.5$ & $231[215]$ & $2.47(0.39)$ \\
\hline Overall mean & 32 & $117.4(0.7)$ & $0.277(0.004)$ & $7.4(0.6)$ & $3.1-7.1$ & $178[134]$ & $2.12(0.23)$ \\
\hline
\end{tabular}



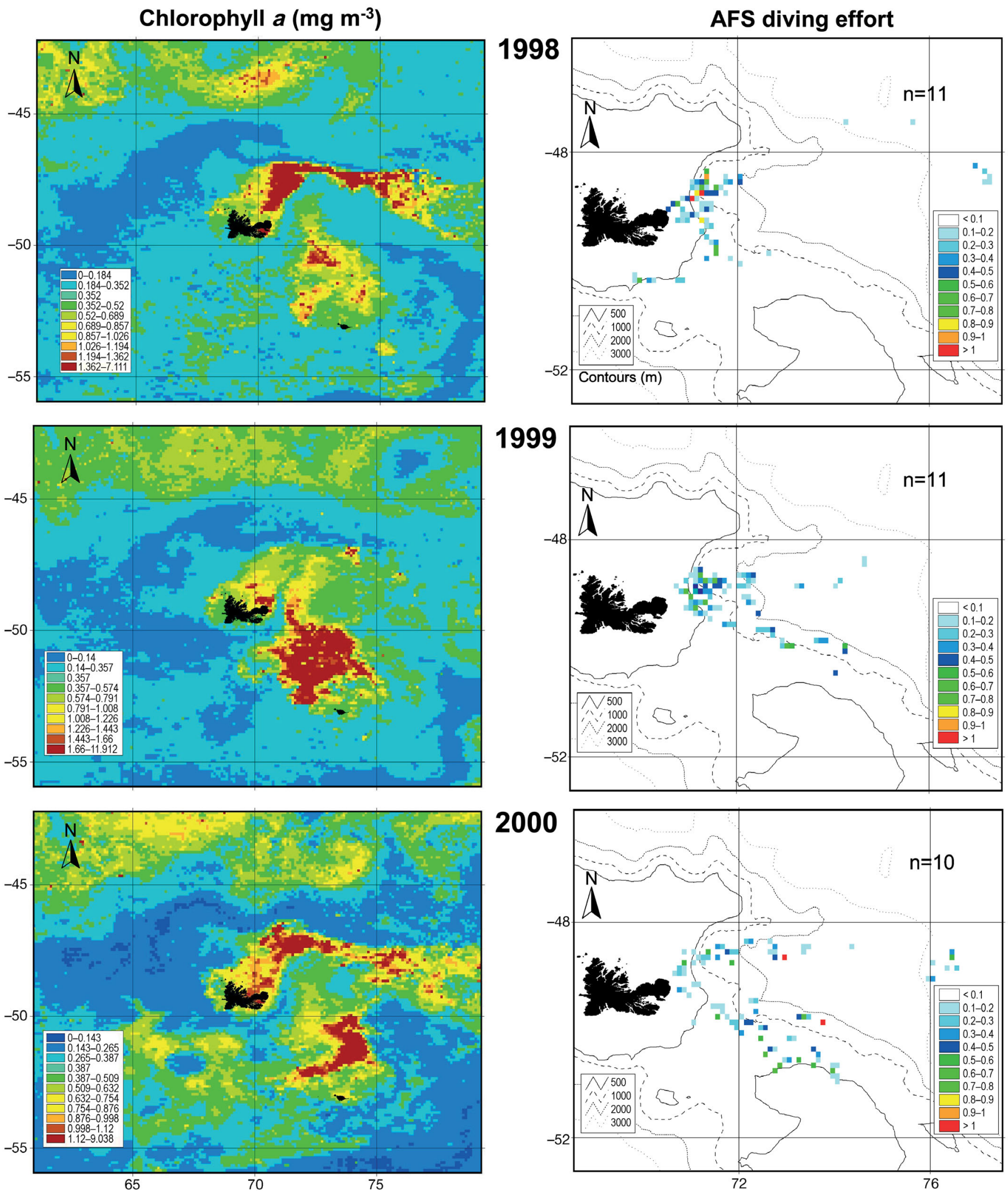

Fig. 2. Chlorophyll a concentrations in region surrounding Kerguelen Plateau in February 1998, 1999 and 2000. Data from PODAAC (Physical Oceanography Distributed Active Archive Center) and time spent diving (seal hours per $0.1^{\circ} \times 0.1^{\circ}$ pixel of latitude and longitude) by foraging Antarctic fur seals Arctocephalus gazella (AFS) in 1998, 1999 and 2000. Pixels visited for <0.1 seal hours were assumed to be transit regions and are not coloured 

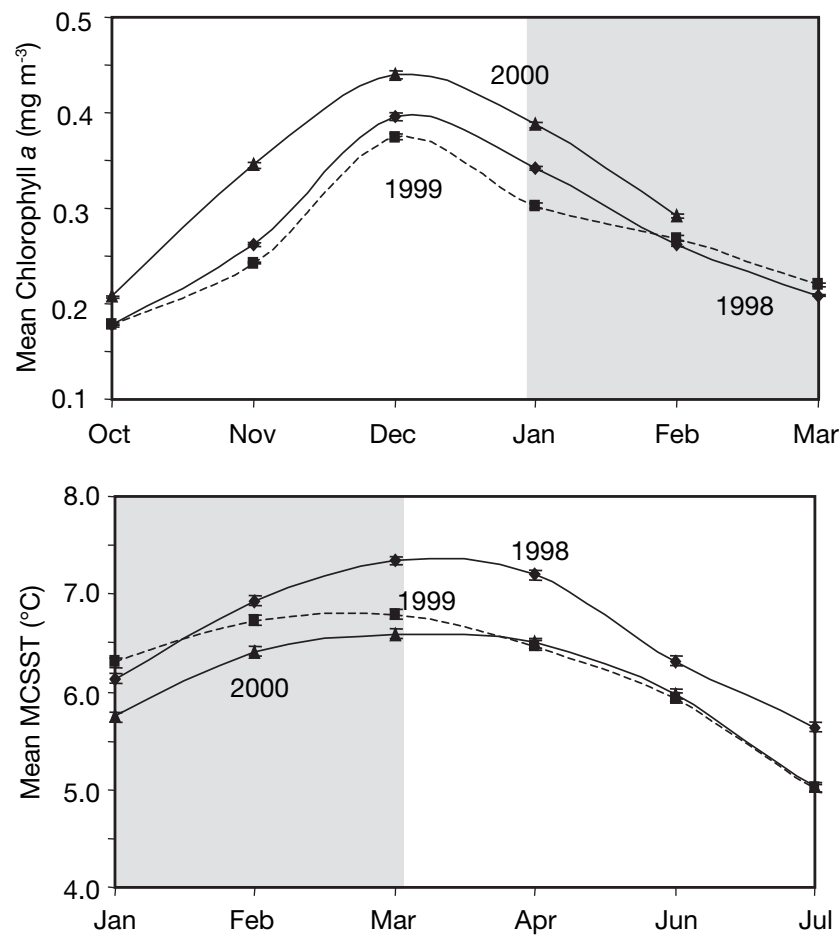

Fig. 3. Mean sea surface temperatures, MCSST $( \pm \mathrm{SE})$ and chlorophyll a concentration within a $750 \mathrm{~km}$ radius of a Cap Noir Antarctic fur seal Arctocephalus gazella colony. Study period is shaded; $750 \mathrm{~km}$ area $=5428$ pixels $($ MCSST) and 22115 pixels (chlorophyll a)

The general spatial distribution of the diving effort of AFS females appears to correspond with the general distribution of chlorophyll a over the 3 study years (Fig. 2). In 1998, all areas of high diving activity ( $>0.8$ seal hours usage) occurred over the peri-insular shelf break (500 to $1000 \mathrm{~m}$ ) within $100 \mathrm{~km}$ of Cap Noir. In 1999 and 2000 the distribution of diving activity was more dispersed. In 1999 areas of highest diving activity again occurred on the margins of the peri-insular shelf $(<500 \mathrm{~m})$ to the NE of the colony, however a second region, approximately $300 \mathrm{~km}$ to the SE, was also used by the seals. In 2000, a bimodal distribution was evident, with seals foraging further afield over deeper water, in areas corresponding to chlorophyll a plumes (Fig. 2). The water depth (mean $=1160 \pm 111 \mathrm{~m}$ ) of regions visited by seals was identical between years (ANOVA, $\left.F_{2,29}=0.205, \mathrm{p}=0.815\right)$. Seals tended to avoid the peri-insular shelf, spending the majority of their time over the peri-insular shelf break (38 $\pm 5 \%$ ) and in oceanic waters $(48 \pm 7 \%)$, as confirmed by 2-way ANOVA $\left(F_{2,87}=10.756, \mathrm{p}<0.001\right)$.

In 1998, average nightly SSTs, as measured by TDR $(4.8 \pm 0.1$, range 4.4 to 6.1$)$ were higher but more homogenous $\left(4\right.$ to $\left.5^{\circ} \mathrm{C}\right)$ than those in $1999(4.7 \pm 0.2$, range 3.6 to 6.2$)$ and $2000(4.5 \pm 0.2$, range 3.8 to 5.5$)$, regardless of whether seals foraged $\mathrm{NE}$ or $\mathrm{SE}$ of the

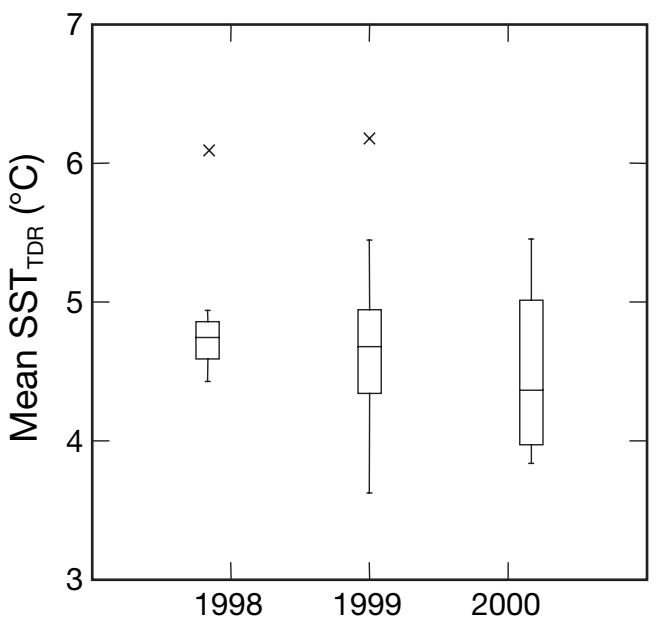

Fig. 4. Mean nightly sea surface temperatures (SST) for each study year, measured by time-depth recorders on female Arctocephalus gazella tracked from Cap Noir in 1998, 1999 and 2000. $\times$ : outliers

colony (Fig. 4). In all years the highest nightly SSTs were recorded by 3 seals, which travelled in long arcing loops to the north and east of Îles Kerguelen in the vicinity of the SAF.

Diving behaviour. The diving activity of the 32 seals equipped with PTT/TDRs in February represented a total of 48378 dives and 238 seal days foraging. Mean time spent diving per foraging trip was greater in 1999 than in 2000 (Table 3, 25 vs. $21 \%$ ), whilst the more deeply diving seals in 1998 conducted a significantly greater proportion of their foraging effort at night $(97.0 \%)$ than seals in other years $(81.5$ to $86.9 \%)$. The cumulative depth dived per day did not vary between years (Table 3), however dive frequency in 1998 was significantly lower than in subsequent years, being negatively correlated with mean dive depth (Pearson's correlation coefficient, $\left.\mathrm{PCC}_{32}=-0.740, \mathrm{p}<0.001\right)$.

Attendance patterns and device effects. SB and FTD were similar for females fitted with small VHF transmitters (control) and those carrying larger PTT packages, when compared by generalised linear model $($ GLM) (treatment $=$ fixed and year $=$ random). There was no interaction effect between treatment and year on foraging trip duration $\left(F_{2,81}=1.368, \mathrm{p}=0.260\right)$, indicating that foraging behaviour of PTT females was similar to that of the control seals and the effect of carrying device packages was minimal. SB $(2.1 \pm 0.1 \mathrm{~d}$, $\mathrm{n}=54)$ and FTD $(8.5 \pm 0.3 \mathrm{~d}, \mathrm{n}=54)$ of control AFS during late lactation were similar between years (SB: $F_{2,52}=0.715, \mathrm{p}=0.494 ;$ FTD: $F_{2,52}=1.951, \mathrm{p}=$ 0.152 ). However, provisioning variability (SE around mean seal FTD) was significantly less variable in 2000 than in 1998 and $1999\left(F_{2,49}=4.612, \mathrm{p}<0.05\right.$, Fig. 5). No significant differences in SB expressed as a pro- 
Table 3. Arctocephalus gazella. Inter-annual variation in environmental conditions (SST and bathymetry) in seal foraging zones and diving parameters for female Antarctic fur seals equipped with PTT/TDR units (mean \pm SE). -: no significant difference between years

\begin{tabular}{|c|c|c|c|c|c|c|c|}
\hline Year & $\begin{array}{c}1998 \\
(\mathrm{n}=11)\end{array}$ & $\begin{array}{c}1999 \\
(\mathrm{n}=11)\end{array}$ & $\begin{array}{c}2000 \\
(\mathrm{n}=10)\end{array}$ & df & F-ratio & $\mathrm{p}$ & Tukey HSD \\
\hline Mean bathymetry (km) & $1.11 \pm 0.24$ & $1.28 \pm 0.18$ & $1.08 \pm 0.27$ & 2,29 & 0.208 & 0.813 & - \\
\hline $\mathrm{SST}_{(\mathrm{TDR})}$ & $4.83 \pm 0.14$ & $4.74 \pm 0.20$ & $4.47 \pm 0.18$ & 2,29 & 1.149 & 0.331 & - \\
\hline Trip duration (d) & $7.0 \pm 1.1$ & $7.3 \pm 1.0$ & $8.0 \pm 0.8$ & 2,29 & 0.247 & 0.783 & - \\
\hline Time spent diving (\%) & $21.2 \pm 1.2$ & $24.9 \pm 1.4$ & $20.8 \pm 1.1$ & 2,29 & 3.580 & $<0.05$ & $1999>2000$ \\
\hline$\%$ dives at night & $97.0 \pm 1.0$ & $81.5 \pm 3.8$ & $86.9 \pm 5.3$ & 2,29 & 7.335 & $<0.01$ & $1998>1999$ \\
\hline$\%$ vertical depth at night & $97.6 \pm 1.3$ & $71.1 \pm 4.5$ & $90.1 \pm 3.1$ & 2,29 & 20.212 & $<0.001$ & $1999<1998,2000$ \\
\hline Cumulative depth $\left(\mathrm{km} \mathrm{d}^{-1}\right)$ & $11.0 \pm 0.84$ & $11.9 \pm 0.77$ & $10.5 \pm 0.90$ & 2,29 & 0.753 & 0.480 & - \\
\hline Dive rate $\left(\mathrm{h}^{-1}\right)$ & $6.9 \pm 0.6$ & $9.3 \pm 0.6$ & $9.2 \pm 0.9$ & 2,29 & 3.798 & 0.034 & $1998<1999,2000$ \\
\hline Mean dive depth (m) & $69.1 \pm 5.0$ & $56.1 \pm 5.5$ & $51.8 \pm 7.2$ & 2,29 & 2.334 & 0.115 & - \\
\hline
\end{tabular}

portion of the mean FC (1998: $19.2 \pm 1.3 \%$; 1999: $21.6 \pm 0.7 \%$; and 2000: $20.4 \pm 0.8 \%)$ were detected between years $\left(F_{2,52}=1.399, \mathrm{p}=0.256\right)$.

Over the 3 study years, the FTD of AFS tracked by satellite telemetry were positively correlated with mean ocean depth ( $\left.\mathrm{PCC}_{32}=0.588, \mathrm{p}<0.001\right)$, mean $\mathrm{SST}_{\mathrm{TDR}}$ $\left(\mathrm{PCC}_{32}=0.363, \mathrm{p}<0.05\right)$ and maximum distance travelled from the colony $\left(\mathrm{PCC}_{28}=0.905, \mathrm{p}<0.001\right)$ during a foraging trip.

Dietary composition and prey availability. Identifiable prey remains were extracted from 131 scats (1998: $\mathrm{n}=60 ; 1999: \mathrm{n}=24 ; 2000: \mathrm{n}=47)$. In 1998, the fish diet of fur seals was more varied, with 28 species of fishes consumed, compared with 18 in 1999 and 17 in 2000; 3 species of myctophids (Gymnoscopelus piabilis, G. nicholsi and Electrona subaspera) always constituted the main prey, however, in 1998 myctophids accounted for only $54 \%$ of estimated fish biomass consumption, with species from other fish families, including Champsocephalus gunnari, accounting for $36 \%$ of estimated prey biomass consumed. The proportion of myctophids in the diet increased from $74 \%$ in 1999 to $82 \%$ in 2000 .

The number of prey species caught at depths of $<150 \mathrm{~m}$ was 32 in 1998 and 36 in 1999. The CPUE; fishes $\mathrm{h}^{-1}$ ) of the 3 main fish prey species in the diving range of the fur seals was 2.7 to 12.3 times higher in 1999 than in 1998 (Table 4, Fig. 6). Catch rates of the most common dietary prey species, Gymnoscopelus piabilis, were always relatively low (0.4 to 4.9 CPUE) in comparison with those of G. nicholsi and Electrona subaspera (3.0 to 32.4 CPUE). The catch locations of these 3 species however, did coincide with those areas favoured by AFS in 1998 and 1999 (Fig. 6). Interestingly, the catch rates of species not highly abundant within the fur seals' diet, such as E. antarctica and Krefftichthys anderssoni, were greater than those of the main prey species. Also, there were higher capture rates of non-myctophid fish species in 1998 than in 1999 (Table 4), corresponding to the noted increase in the relative proportion of these fish species in the diet of fur seals in these years.
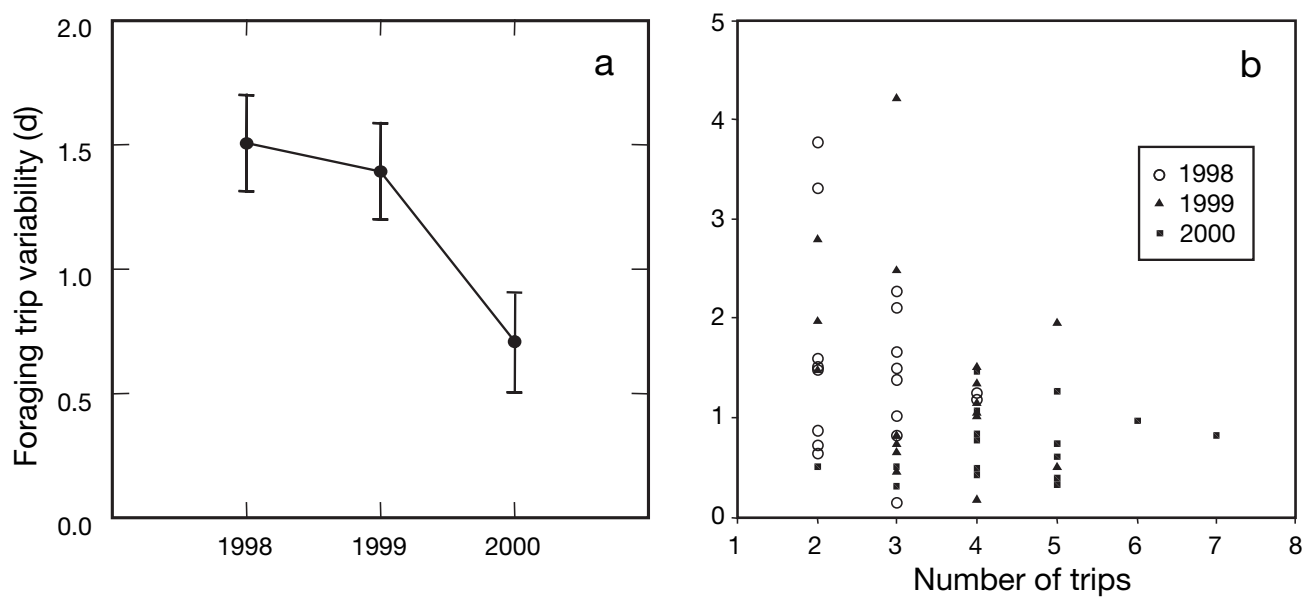

Fig. 5. Arctocephalus gazella. (a) Interannual comparison of maternal provisioning variability calculated as mean foraging trip duration $( \pm$ SE) for Antarctic fur seal females in $1998(\mathrm{n}=18), 1999$ ( $\mathrm{n}=18)$, and 2000 ( $\mathrm{n}=16$ ); (b) relationship between foraging trip variability and sample size 
Table 4. Catch rates (no. of fish and \%), standard length (SL) and catch per unit effort (CPUE) of fishes trawled at $<150 \mathrm{~m}$ depth in Arctocephalus gazella foraging areas in February 1998 and 1999 at 28 sampling stations NE of Îles Kerguelen. -: no data

\begin{tabular}{|c|c|c|c|c|c|c|c|c|}
\hline & \multicolumn{4}{|c|}{1998} & \multicolumn{4}{|c|}{1999} \\
\hline & No. & $\%$ & Mean SL & CPUE & No. & $\%$ & Mean SL & CPUE \\
\hline \multicolumn{9}{|l|}{ Myctophidae } \\
\hline Gymnoscopelus piabilis & 5 & 0.08 & 125.8 & 0.4 & 69 & 1.6 & 124.0 & 4.9 \\
\hline Electrona subaspera & 42 & 0.7 & 77.6 & 3.0 & 112 & 2.5 & 67.0 & 8.0 \\
\hline Gymnoscopelus nicholsi & 135 & 2.1 & 46.8 & 9.6 & 454 & 10.2 & 38.9 & 32.4 \\
\hline Total-main prey species & 182 & 2.8 & - & 13.0 & 635 & 14.3 & - & 45.3 \\
\hline \multicolumn{9}{|l|}{ Other myctophids } \\
\hline Electrona antarctica & 1348 & 20.9 & 50.7 & 96.3 & 1115 & 25.1 & 41.4 & 79.6 \\
\hline Electrona carlsbergi & & & & & 30 & 0.7 & 77.6 & 2.1 \\
\hline Gymnoscopelus fraseri & 133 & 2.1 & 65.4 & 9.5 & 131 & 2.9 & 63.6 & 9.4 \\
\hline Gymnoscopelus braueri & 236 & 3.7 & 50.6 & 16.9 & 144 & 3.2 & 50.0 & 10.2 \\
\hline Gymnoscopelus bolini & - & - & - & - & 8 & 0.2 & 204.5 & 0.6 \\
\hline Gymnoscopelus sp. & - & - & - & - & 1 & 0.02 & & 0.07 \\
\hline Krefftichthys anderssoni & 1085 & 16.8 & 44.1 & 77.5 & 378 & 8.5 & 41.5 & 27.0 \\
\hline Metelectrona ventralis & - & - & - & - & 2 & 0.05 & 56.6 & 0.1 \\
\hline Protomyctophum tenisoni & 1623 & 25.1 & 35.4 & 115.9 & 1036 & 23.3 & 34.7 & 74.0 \\
\hline Protomyctophum choriodon & 10 & 0.2 & 68.0 & 0.7 & 68 & 1.5 & 66.9 & 4.9 \\
\hline Protomyctophum andriashevi & 3 & 0.05 & 63.0 & 0.2 & 10 & 0.2 & 50.2 & 0.7 \\
\hline Protomyctophum bolini & 807 & 12.5 & 48.6 & 57.6 & 710 & 16.0 & 43.6 & 50.7 \\
\hline Total-other myctophids & 5245 & 81.1 & - & 374.6 & 3633 & 81.6 & - & 259.5 \\
\hline \multicolumn{9}{|l|}{ Other fishes } \\
\hline Champsocephalus gunnari & 2 & 0.03 & 171.9 & 0.1 & 3 & 0.07 & 77.1 & 0.2 \\
\hline Other species & 1035 & 16.0 & & 73.9 & 180 & 4.0 & & 12.9 \\
\hline Total of all species & 6464 & 100 & - & 461.7 & 4451 & 100 & - & 317.9 \\
\hline
\end{tabular}

Maternal body condition. The length-body mass relationship for 150 AFS females measured in February 1998 to 2000 was described by the equation Body mass $(\mathrm{kg})=0.673 \times$ length $(\mathrm{cm})-46.957\left(\mathrm{r}^{2}=0.583\right.$, $\left.F_{1,147}=209.293, \mathrm{p}<0.001\right)$. The mean body mass of the seals was significantly higher in 2000 (31.9 kg) than in 1998 (28.6 kg; Table 5) when tested by 1-way ANOVA, while length was similar between years $\left(F_{2,147}=0.315, \mathrm{p}=0.315\right)$. Seals in 2000 were in significantly better condition than in both 1998 and 1999, as reflected by the body condition index $\left(F_{1,147}=\right.$ 10.182, $\mathrm{p}<0.001)$.
Fig. 6. Arctocephalus gazella. Catch per unit effort (fishes $\mathrm{h}^{-1}$ ) for the 3 primary prey species of Antarctic fur seals (Gymnoscopelus piabilis, G. nicholsi and Electrona subaspera) in (•) 1998 and (•) 1999

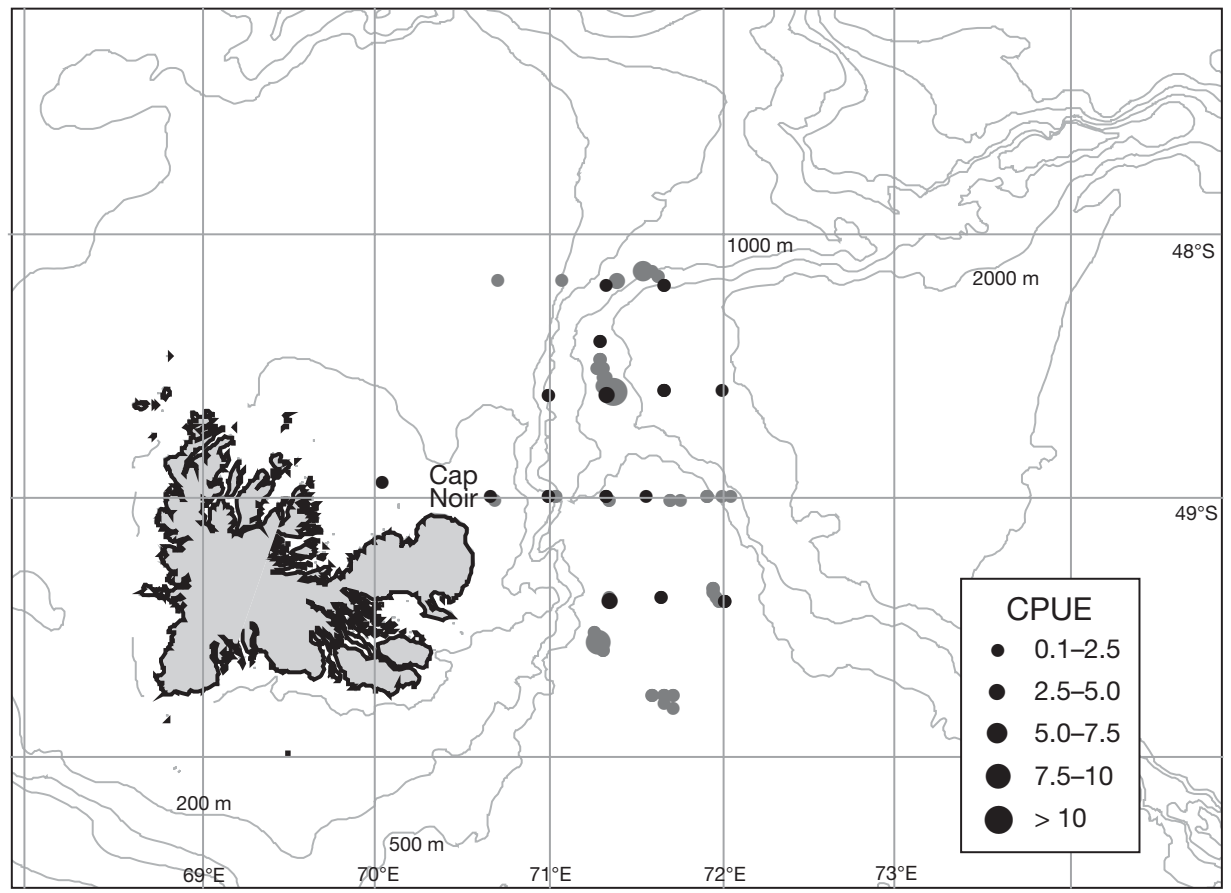




\section{Pup provisioning}

Foraging efficiency. Mass gain per foraging cycle was estimated for 20 mother-pup pairs equipped with PTTs (Table 1). Absolute mass gained by the pup (PMG) was significantly positively related to FTD across the 3 yr combined $\left(F_{1,18}=34.573, \mathrm{p}<0.001, \mathrm{r}^{2}=\right.$ $0.640)$, and consequently was also positively related to dive rate $\left(F_{1,19}=23.845, \mathrm{p}<0.001, \mathrm{r}^{2}=0.546\right)$. Absolute PMG did not vary significantly between years $\left(F_{2,17}=\right.$ 1.268, p $=0.307$ ), nor in relation to female length $\left(F_{1,18}=0.000, \mathrm{p}=0.991\right)$. However, the daily rate of mass gain during the FC was higher in both 1999 $\left(252 \pm 30 \mathrm{~g} \mathrm{~d}^{-1}\right)$ and $2000\left(234 \pm 17 \mathrm{~g} \mathrm{~d}^{-1}\right)$ than in 1998 $\left(168 \pm 15 \mathrm{~g} \mathrm{~d}^{-1}\right),\left(F_{2,17}=4.888, \mathrm{p}<0.05\right.$; Table 6$)$.

Growth rates. Pups were shorter in 1998 than in 1999 and $2000\left(F_{2,235}=28.611, \mathrm{p}<0.001\right)$, and male pups were longer than female pups $\left(F_{1,235}=58.853\right.$, p $<$ $0.001)$, with no interaction effect recorded between sex of the pup and year $\left(F_{2,235}=1.270, \mathrm{p}=0.283\right)$. Mean body mass also varied in relation to both year $\left(F_{2,235}=\right.$ 3.746, $\mathrm{p}<0.001)$ and pup sex $\left(F_{1,235}=129.5, \mathrm{p}<0.001\right)$, with a significant interaction effect $\left(F_{2,235}=25.379, \mathrm{p}<\right.$ 0.05; Table 6).

Mean rates of pup growth ranged from $4 \pm 5 \mathrm{~g} \mathrm{~d}^{-1}$ in 1998, to $66 \pm 5 \mathrm{~g} \mathrm{~d}^{-1}$ in 2000 (Table 6), with 1 male pup attaining $168 \mathrm{~g} \mathrm{~d}^{-1}$ in 1999. Mean growth rates were significantly higher in 2000 than in either 1998 or 1999, and were not correlated with pup sex (2-way ANOVA, $F_{2,235}=0.834, \mathrm{p}=0.362$ ). The rates of pup growth, mean pup body mass and body length in each of the 3 yr were related to maternal length, FTD and provisioning variability (Fig. 7) of those females monitored for attendance using VHF tags. The mean body mass of pups during the study period was positively related to mean FTD only in $1999\left(F_{1,16}=5.653, \mathrm{p}<0.05 ; \mathrm{r}^{2}=0.215\right)$, and growth rates of pups were not related to FTD in any year. Provisioning variability (i.e. SE of FT) was nega-

Table 5. Arctocephalus gazella. Interannual comparisons of maternal and pup body condition (male/female [M, F] pup sample sizes in parentheses) in 1998, 1999 and 2000. BCI: body condition index; TBW: total body water; TBL: total body lipid

\begin{tabular}{|c|c|c|c|c|c|c|c|}
\hline Condition & 1998 & 1999 & 2000 & df & F-ratio & $\mathrm{p}$ & Tukey's HSD \\
\hline \multicolumn{8}{|l|}{ Mothers } \\
\hline $\mathrm{n}$ & 62 & 34 & 54 & & & & \\
\hline Body mass (kg) & $28.6 \pm 0.6$ & $30.6 \pm 0.8$ & $31.9 \pm 0.7$ & 2,147 & 7.129 & $<0.01$ & $1998<2000$ \\
\hline Length $(\mathrm{cm})$ & $113.8 \pm 0.8$ & $115.5 \pm 0.7$ & $115.0 \pm 0.7$ & 2,147 & 1.165 & 0.315 & \\
\hline $\mathrm{BCI}$ & $-1.09 \pm 0.34$ & $-0.21 \pm 0.60$ & $1.41 \pm 0.42$ & 2,147 & 10.182 & $<0.001$ & $1998,1999<2000$ \\
\hline Body condition $\left(\mathrm{kg} \mathrm{cm}^{-1}\right)$ & $0.250 \pm 0.004$ & $0.264 \pm 0.006$ & $0.276 \pm 0.005$ & 2,147 & 9.775 & $<0.001$ & $1998<2000$ \\
\hline \multicolumn{8}{|l|}{ Pups } \\
\hline & $23(11 / 12)$ & $30(14 / 16)$ & $18(7 / 11)$ & & & & \\
\hline \multicolumn{8}{|l|}{ Body mass (kg) } \\
\hline Males & $8.4 \pm 0.5$ & $12.1 \pm 0.4$ & $13.0 \pm 0.6$ & 2,29 & 24.65 & $<0.001$ & $1998<1999,2000$ \\
\hline Females & $8.3 \pm 0.6$ & $10.7 \pm 0.4$ & $10.5 \pm 0.5$ & 2,36 & 8.49 & $<0.001$ & $1998<1999,2000$ \\
\hline \multicolumn{8}{|l|}{ TBW (kg) } \\
\hline Males & $5.3 \pm 0.3$ & $7.4 \pm 0.2$ & $7.6 \pm 0.3$ & 2,29 & 19.74 & $<0.001$ & $1998<1999,2000$ \\
\hline Females & $5.1 \pm 0.3$ & $6.4 \pm 0.2$ & $6.2 \pm 0.3$ & 2,36 & 9.89 & $<0.001$ & $1998<1999,2000$ \\
\hline TBW (\%) & $62.4 \pm 1.0$ & $60.8 \pm 0.6$ & $59.0 \pm 0.5$ & 2,65 & 4.62 & $<0.05$ & $1998>2000$ \\
\hline TBL (\%) & $13.9 \pm 0.9$ & $15.3 \pm 0.5$ & $16.8 \pm 0.5$ & 2,65 & 4.24 & $<0.05$ & $1998<2000$ \\
\hline
\end{tabular}

Table 6. Arctocephalus gazella. Comparisons of pup growth performance, mean body size and provisioning rates between years. Male/female sample sizes in parentheses after years. SL: standard length; PMG: pup mass gain

\begin{tabular}{|c|c|c|c|c|c|c|c|}
\hline Parameter & $1998(47 / 50)$ & $1999(25 / 28)$ & $2000(43 / 48)$ & df & F-ratio & $\mathrm{p}$ & Tukey's HSD \\
\hline \multicolumn{8}{|c|}{ Mean mass (kg) } \\
\hline Male & $9.4 \pm 0.3$ & $11.6 \pm 0.3$ & $11.5 \pm 0.3$ & 2,112 & 20.52 & $<0.01$ & $1998<1999,2000$ \\
\hline Female & $8.6 \pm 0.2$ & $9.7 \pm 0.3$ & $9.6 \pm 0.2$ & 2,123 & 5.75 & $<0.01$ & $1998<1999,2000$ \\
\hline Pooled & $9.0 \pm 0.2$ & $10.6 \pm 0.3$ & $10.5 \pm 0.2$ & 2,238 & 20.01 & $<0.01$ & $1998<1999,2000$ \\
\hline \multicolumn{8}{|c|}{ Mean SL (cm) } \\
\hline Male & $77.2 \pm 0.7$ & $82.2 \pm 0.6$ & $81.7 \pm 0.6$ & 2,112 & 18.80 & $<0.01$ & $1998<1999,2000$ \\
\hline Female & $74.2 \pm 0.6$ & $78.0 \pm 0.7$ & $76.9 \pm 0.5$ & 2,123 & 10.26 & $<0.01$ & $1998<1999,2000$ \\
\hline Pooled & $75.7 \pm 0.5$ & $80.0 \pm 0.5$ & $79.1 \pm 0.5$ & 2,238 & 21.92 & $<0.01$ & $1998<1999,2000$ \\
\hline \multicolumn{8}{|c|}{ Growth rate $\left(\mathrm{g} \mathrm{d}^{-1}\right)$} \\
\hline Male & $7 \pm 6$ & $10 \pm 12$ & $77 \pm 7$ & 2,112 & 26.90 & $<0.01$ & $1998,1999<2000$ \\
\hline Female & $1 \pm 7$ & $18 \pm 12$ & $56 \pm 6$ & 2,123 & 14.38 & $<0.01$ & $1998,1999<2000$ \\
\hline Pooled & $4 \pm 5$ & $14 \pm 8$ & $66 \pm 5$ & 2,238 & 38.70 & $<0.01$ & $1998,1999<2000$ \\
\hline \multicolumn{8}{|c|}{ Daily PMG $\left(\mathrm{g} \mathrm{d}^{-1}\right)$} \\
\hline Pooled & $168 \pm 15(7)$ & $252 \pm 30(5)$ & $234 \pm 17(8)$ & 2,17 & 4.882 & $<0.05$ & $1998<1999,2000$ \\
\hline
\end{tabular}


tively related to log transformed pup growth rates and mean body mass of pups when data from all years were combined $\left(F_{1,37}=14.276\right.$, $\mathrm{r}^{2}=0.259, \mathrm{p}<0.01$ and $F_{1,37}=4.354, \mathrm{r}^{2}=$ $0.081, \mathrm{p}<0.05)$. However, when separated by year, the relationship was significant only in $1999\left(F_{1,6}=6.023, \mathrm{r}^{2}=0.418, \mathrm{p}<0.05\right.$ and $F_{1,6}=6.982, \mathrm{r}^{2}=0.461, \mathrm{p}<0.05$ respectively). In addition, higher mean body masses and body lengths of pups were positively related to maternal size in 1998, $\left(F_{1,18}=8.024, \mathrm{p}<\right.$ $0.05, \mathrm{r}^{2}=0.270$ and $F_{1,18}=5.653, \mathrm{p}<0.01, \mathrm{r}^{2}=$ 0.312 respectively).

Pup body condition. Body mass was positively related to pup length $\left(F_{1,186}=482.796\right.$, $\left.\mathrm{p}<0.001 ; \mathrm{r}^{2}=0.720\right)$. Length and body mass of the pups varied in relation to pup sex $\left(F_{1,182}=\right.$ 34.67, $\mathrm{p}<0.001$ and $F_{1,182}=20.53, \mathrm{p}<0.001$ respectively) and year (Table 7), with no interaction effects. The body condition index (BCI) however varied between years (Table 7 ) but not in relation to pup sex $\left(F_{1,182}=0.802, \mathrm{p}=\right.$ 0.372). Female pup length was similar between years, whilst male pups were significantly longer in both 1999 and 2000 than in 1998. Body mass and BCI were always higher in 2000 than in 1998 for both male and female pups, with measurements in 1999 often intermediate. The absolute total body weight (TBW) of 71 pups was significantly related to body mass in all 3 years (Table 7). All pups weighed less and had significantly lower absolute levels of TBW in 1998 than in 1999 and 2000 (Table 5). Lower proportional TBW and total body lipid (TBL) indicate that pups were in poorer condition in 1998.

\section{DISCUSSION}

Climatic anomalies and their effects on local and regional environmental conditions are known to impact the behaviour and reproductive success of marine predators (Guinet et al. 1994, 1998a, Georges et al. 2000, Inchausti et al. 2003, Weimerskirch et al. 2003). In longlived and far-ranging species (Field et al. 2001, Nel et al. 2001), the effects of localised changes in oceanography and marine production may be minimised by changes in the location of foraging zones. However for mammalian central place foragers such as lactating otariids, the responsibility of parental care rests solely with the mother and is largely determined by her ability to efficiently locate prey within a limited geographic region (Bonner 1984). Local environ-
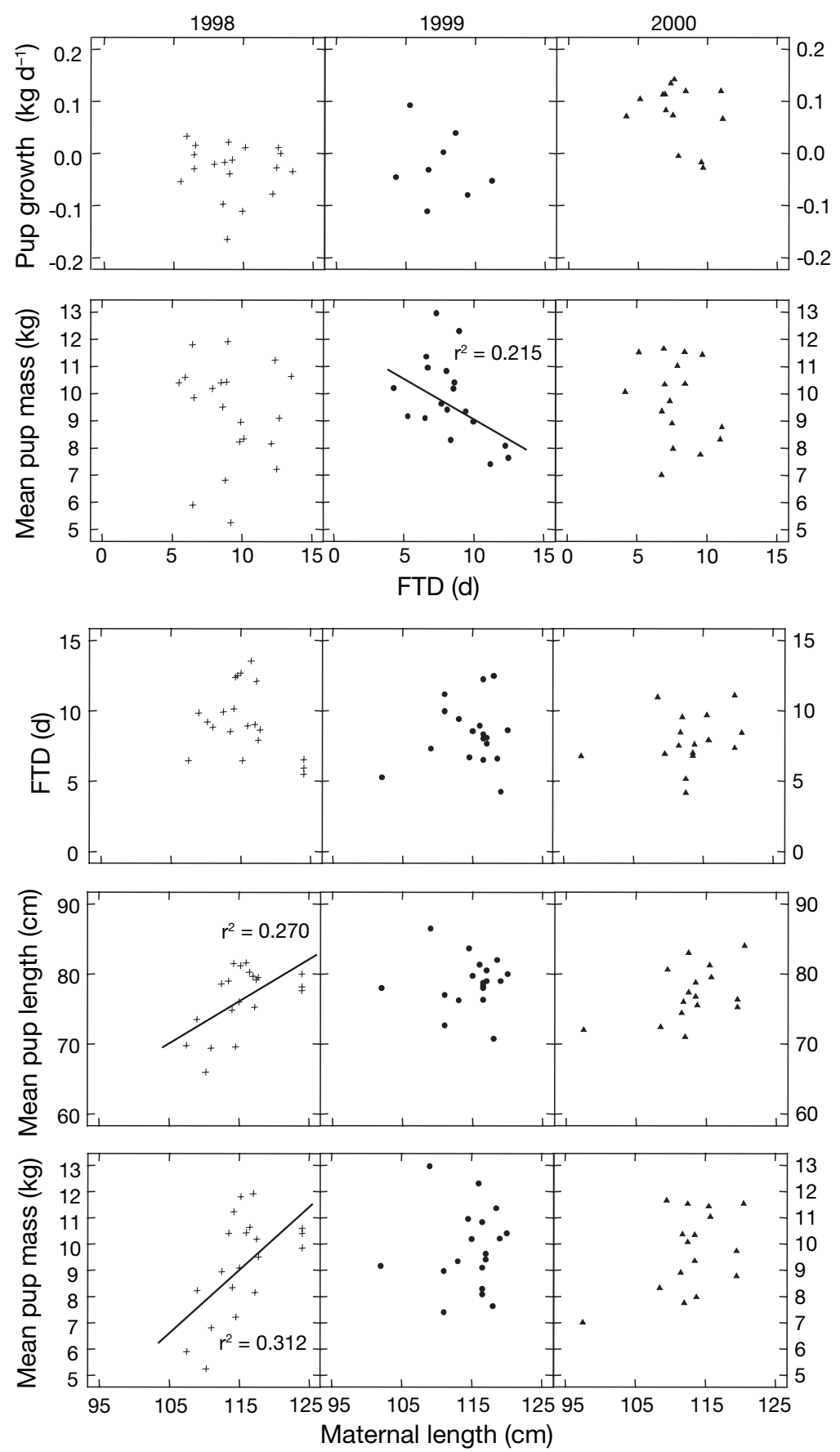

Fig. 7. Arctocephalus gazella. Relationships between maternal characteristics (foraging trip duration and length) and pup parameters (growth rates, mean body mass and length) in 1998, 1999 and 2000

mental conditions can affect offspring size and body condition and ultimately the survivability of pups and juveniles through maternal resource acquisition strategies (Soto et al. 2004). The maternal mediation of environmental changes influencing prey availability depends on both maternal traits (Lunn \& Boyd 1993b, Pomeroy et al. 1999, Georges \& Guinet 2000, this study) 
Table 7. Arctocephalus gazella. Body mass, standard length and body condition index (BCI) of pups in early March 1998, 1999 and 2000, tested by 1-way ANOVA with year as factor. Male/female samples sizes of pups in parentheses after years. ns: not significant

\begin{tabular}{|lrrrrrrr}
\hline Parameter & $1998(24 / 29)$ & $1999(52 / 40)$ & $2000(21 / 22)$ & df & F-ratio & p & Tukey's HSD \\
\hline Body mass $(\mathrm{kg})$ & & & & & & & \\
Male & $9.7 \pm 0.5$ & $11.4 \pm 0.3$ & $13.0 \pm 0.6$ & 2,94 & 10.89 & $<0.001$ & $1998<1999<2000$ \\
Female & $9.1 \pm 0.4$ & $10.1 \pm 0.3$ & $10.6 \pm 0.3$ & 2,88 & 4.41 & 0.019 & $1998<2000$ \\
Pooled & $9.4 \pm 0.3$ & $10.8 \pm 0.2$ & $11.8 \pm 0.4$ & 2,185 & 13.78 & $<0.001$ & $1998<1999,2000$ \\
Body length (cm) & & & & & & \\
Male & $80.4 \pm 1.0$ & $83.5 \pm 0.5$ & $83.9 \pm 1.1$ & 2,94 & 4.91 & 0.009 & $1998<1999,2000$ \\
Female & $78.2 \pm 0.8$ & $79.1 \pm 0.6$ & $79.0 \pm 0.7$ & 2,88 & 0.43 & $\mathrm{~ns}$ & \\
Pooled & $79.2 \pm 0.7$ & $81.6 \pm 0.5$ & $81.4 \pm 0.8$ & 2,185 & 4.79 & 0.000 & $1998<1999$ \\
BCI & & & & & & \\
Male & $-0.69 \pm 0.25$ & $-0.33 \pm 0.17$ & $1.06 \pm 0.28$ & 2,94 & 12.73 & $<0.001$ & $1998<1999,2000$ \\
Female & $-0.40 \pm 0.20$ & $0.18 \pm 0.15$ & $0.73 \pm 0.24$ & 2,88 & 7.38 & 0.001 & $1998<2000$ \\
Pooled & $-0.53 \pm 0.16$ & $-0.11 \pm 0.12$ & $0.89 \pm 0.18$ & 2,185 & 18.53 & $<0.001$ & $1998<1999,2000$ \\
\hline
\end{tabular}

and probably foraging experience (Bonadonna et al. 2001).

This 3 yr study of an SO myctophid predator-prey relationship has demonstrated that virtually all parameters relating to otariid foraging behaviour, such as the location of feeding zones, diving activity and diet, vary concurrently with changing oceanographic conditions and food availability in the PFZ at Îles Kerguelen (Table 8). The body condition of both mothers and pups showed extreme variation between years, and were lowest in 1997/98, the strongest El Niño event on record in the Pacific Ocean (Grotzner et al. 2000), which corresponded with anomalously warm SST (Fig. 8) and the highest positive sea surface height anomaly recorded in the Kerguelen region (Park et al. 1998). Only in 1998 did maternal size positively influence pup mass and pup size in late lactation, even though pup growth rates were, on average, negligible. However, the large-scale breeding failures which have been reported at other otariid breeding sites affected by climatic anomalies (Trillmich \& Dellinger 1991, Soto et al. 2004), for example Bird Island (Atlantic sector of SO, South Georgia), where seals depend almost exclusively on krill Euphausia superba (Boyd et al. 1995), were not observed.

\section{Prey fluctuations and environmental conditions}

Environmental conditions were highly variable within the foraging range of AFS between years (Guinet et al. 2001, this study). Warm SST anomalies occur in the
Kerguelen region within 1 yr and again 4 to 5 yr after an El Niño, and have previously coincided with depressed breeding performance and body condition in blue petrels Halobaena caerulea (Guinet et al. 1998a) and changing seal population numbers (Guinet et al. 1994). At the Kerguelen Archipelago in 1998, the occurrence of anomalously warm waters coincided with depressed pup growth rates, poor female and pup body condition, and reduced prey availability in terms of abundance and species occurrence. Larger, and

Table 8. Arctocephalus gazella. Summary of environmental, maternal acquisition and allocation parameters for females at îles Kerguelen, 1998 to 2000. BDG1: Behavioural dive group 1 (Lea et al. 2002c); -: no data. Primary prey were Gymnoscopelus nicholsi, G. piabilis and Electrona subaspera. MCSST: mean sea surface temperature; ENV: environment; POP: population; IND: individually tracked seals; other abbreviations as in Table 1 \& 5

\begin{tabular}{|c|c|c|c|c|}
\hline Parameter & Class & 1998 & 1999 & 2000 \\
\hline \multicolumn{5}{|l|}{ Environmental parameters } \\
\hline Mean MCSST $\left({ }^{\circ} \mathrm{C}\right)$ & ENV & 6.9 & 6.7 & 6.4 \\
\hline TDR nightly SST $\left({ }^{\circ} \mathrm{C}\right)$ & IND & 4.8 & 4.8 & 4.5 \\
\hline Mean chlorophyll a $\left(\mathrm{mg} \mathrm{m}^{-3}\right)$ & ENV & 0.263 & 0.269 & 0.292 \\
\hline Mean bathymetry (m) & ENV & 1088 & 1257 & 1130 \\
\hline \multicolumn{5}{|l|}{ Diet } \\
\hline Proportion of myctophids (\%) ${ }^{\mathrm{a}}$ & POP & 54 & 74 & 82 \\
\hline No. fish taxa consumed & POP & 28 & 18 & 17 \\
\hline \multicolumn{5}{|l|}{ Prey availability } \\
\hline CPUE of primary prey & ENV & Low & High & - \\
\hline \multicolumn{5}{|l|}{ Maternal acquisition } \\
\hline Med. max. distance $(\mathrm{km})$ & IND & 111 & 113 & 215 \\
\hline Proportion deep divers (BDG1)b & IND & $82 \%$ & $55 \%$ & $50 \%$ \\
\hline Body condition index, BCI & POP & -1.09 & -0.21 & 1.37 \\
\hline Trip duration (d) & POP & 9.3 & 8.4 & 7.8 \\
\hline \multicolumn{5}{|l|}{ Pup allocation } \\
\hline TBW\% & POP & Low & Intermediate & High \\
\hline $\mathrm{BCI}, \mathrm{M}$ & POP & Low & Low & High \\
\hline $\mathrm{BCI}, \mathrm{F}$ & POP & Low & Intermediate & High \\
\hline Mean March body mass (kg) & POP & Low & Intermediate & High \\
\hline Growth rates ( 30 to $65 \mathrm{~d}$ ) $\mathrm{g} \mathrm{d}^{-1}$ & POP & Zero & Low & High \\
\hline Milk fat (mean \% lipid) ${ }^{a}$ & POP & - & $43.3 \%$ & $53.2 \%$ \\
\hline
\end{tabular}




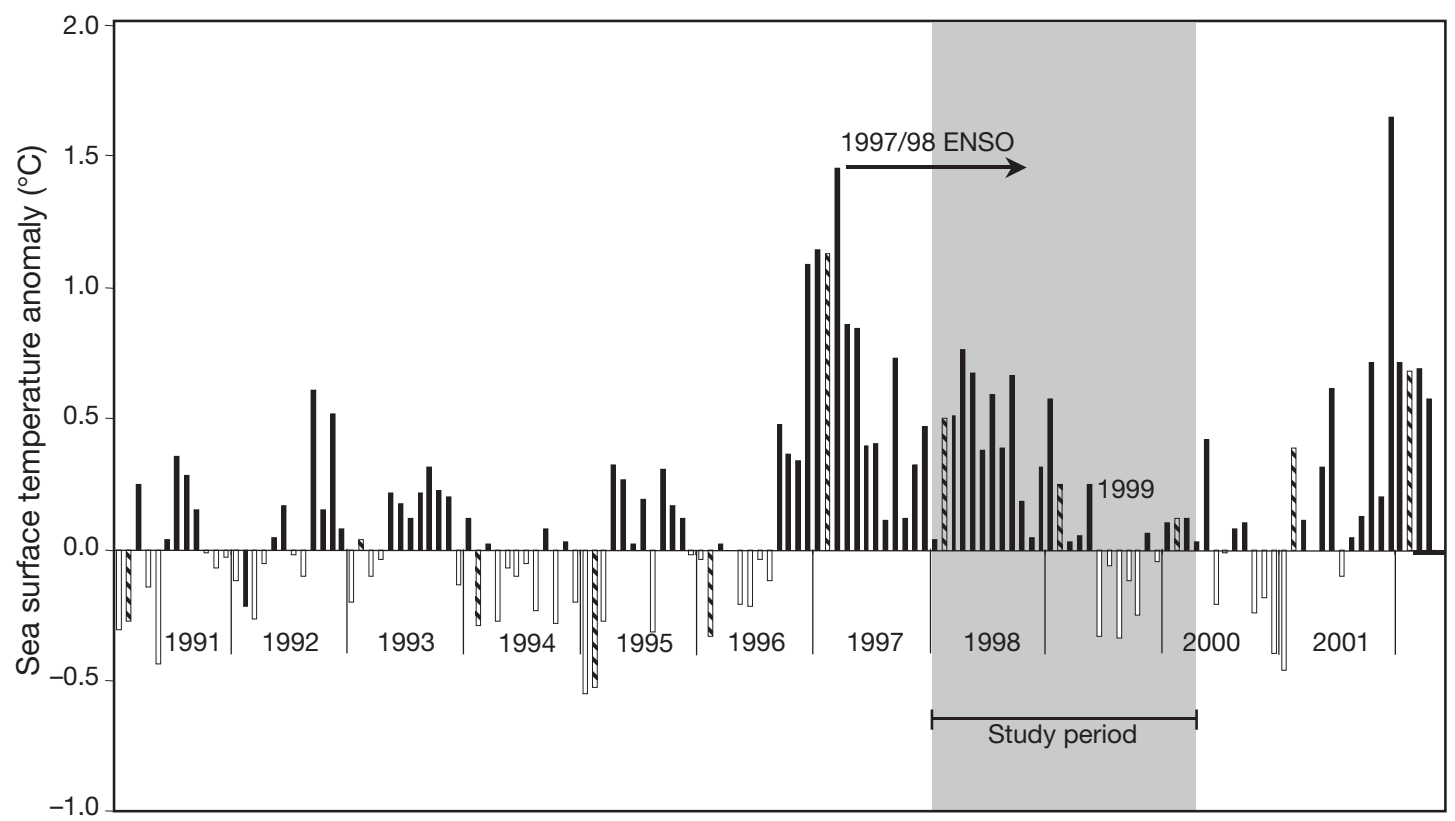

Fig. 8. Monthly sea surface temperature anomaly (SSTA) measurements from ship, buoy and bias-corrected satellite data from 1991 to 2002 (Reynolds \& Smith 1994), in area encompassing foraging zones of Arctocephalus gazella $\left(46.5^{\circ} \mathrm{S}, 69.5^{\circ} \mathrm{E}\right.$ to $52.5^{\circ} \mathrm{S}$, $\left.75.5^{\circ} \mathrm{E}\right)$. Black bars: positive SSTA $\left({ }^{\circ} \mathrm{C}\right)$; white bars: negative SSTA $\left({ }^{\circ} \mathrm{C}\right)$; dashed bars: all February values from 1991 to 2002

potentially older, mothers monitored throughout the breeding season were better able to provision their young in this year. Anomalous warm SSTs have previously been linked to the occurrence of longer foraging trips in Juan Fernandez fur seals (Francis et al. 1998), presumably associated with reduced foraging success.

At Kerguelen, prey availability (measured by CPUE of myctophids in the fur seals' foraging zone) was low in 1998, coinciding with warmer SST. However increases in CPUE of 200 to $700 \%$ were recorded for the 3 main prey species in 1999. The spatial distribution of seals in 1998 coincided with the highest availability of fish prey for that year (Guinet et al. 2001) located approximately 60 to $70 \mathrm{~km} \mathrm{NE}$ of the colony. The foraging location of seals in both 1998 and 1999 also corresponded with the highest captures of the 3 preferred myctophid prey species, Gymnoscopelus piabilis, G. nicholsi and Electrona subaspera. In both years, however, there was considerable disparity between the abundance of these main prey species within the diet and trawl samples, perhaps due to prey selectivity by the seals, or a higher incidence of these particular species at greater depths not sampled during trawls, and/or net avoidance behaviour by the larger prey species. The coupling of acoustic surveys with trawl sampling (acoustic echo-integration) in the future could address this issue.

Interannual variability was also reflected in the dietary preferences of seals, with the number of prey species taken per scat being more variable in the year of lower overall prey abundance or accessibility (1998) than in 2000. Although no prey capture data are available for 2000, this is assumed to be a year of high food availability, given the higher body condition index recorded for lactating females in this year. The increasing incidence of the energy-rich species, Gymnoscopelus piabilis and G. nicholsi, in the diet of fur seals from 1998 to 2000 is reflected in the higher body condition indices of females observed over the $3 \mathrm{yr}$. We hypothesise that the injection of warmer surface waters during the ENSO may significantly alter the species composition and/or availability of certain myctophid species in the PFZ, directly influencing the energy consumption of female AFS during the breeding season.

\section{Maternal allocation and pup provisioning}

Growth rates, average size and body condition of pups in March were all lowest in 1998, indicating that most females were not able to fully compensate for lower levels of prey quality and abundance by altering their foraging behaviour. Our measure of foraging efficiency, the rate of daily mass gain over a foraging cycle, was also significantly lower during that year.

Reductions in provisioning rates are common amongst otariids exposed to annual or seasonal changes in prey abundance (Francis et al. 1998, Goldsworthy 1999). At South Georgia in a year of low prey availability, pup 
growth rates were negatively related to maternal foraging trip duration (Lunn \& Boyd 1993b), as was the case for Arctocephalus tropicalis over the course of a year (Georges \& Guinet 2000). Although the mean FTD $(8.5 \pm 0.3 \mathrm{~d})$ recorded at Cap Noir is the longest reported for AFS at any breeding site, there was no direct correlation between average growth rates of pups over the study and mean provisioning rates of mothers. The absolute mass gained by a pup, however, was positively related to FTD, as is the case at Macquarie Island (Guinet et al. 1999). Interestingly, daily pup mass gain, expressed in relation to the duration of the previous foraging cycle, did differ between years, indicating that females were more efficient at transferring energy to the pup in years of greater prey availability.

Overall, pup growth rates and mean body mass and length were significantly higher in 2000 than in other years. Although prey abundance was higher in 1999 than in 1998, female body condition did not reach maximum levels until 2000. The seals' milk in 2000 had a significantly higher lipid content than in 1999 (Lea et al. 2002b, 2003), and contained high quantities of monounsaturated fatty acids, reflecting a diet high in energy-rich myctophids.

\section{Maternal acquisition strategies}

Under conditions of variable prey availability in the foraging range of AFS, females should adjust their activity budget in order to maximise their chances of foraging success (Houston \& Carbone 1992, Boyd 1999, Mori \& Boyd 2004). At Kerguelen, the spatial distribution and diving activity of seals during years of differing prey availability varied markedly. Individual variation in the way seals responded to their altered environment, however, accounted for much of the variability in diving behaviour. A common measure of foraging effort often recorded in fur seal populations is foraging trip duration (Costa et al. 1991, Francis et al. 1998, McCafferty et al. 1998, Georges \& Guinet 2000). However, at Cap Noir, despite considerable interannual fluctuations in marine productivity, no significant differences in FTD were observed. Rather, provisioning variability proved to be of greater significance. Seals making longer foraging trips displayed a higher degree of variability in trip duration. Foraging trips were more consistent in duration in 2000 and AFS were in better condition in this year than in 1998 and 1999. This variability in trip duration, however, was negatively correlated with pup mass and individual pup growth rates in late lactation only in the intermediate year, 1999. Georges \& Guinet (2000) also observed a similar relationship between provisioning variability and pup growth rates for Arctocephalus tropicalis pups at Amsterdam Island, while studies of other top predators, such as the wandering albatross Diomedea exulans (Weimerskirch et al. 2000) have highlighted, the importance of regularity in provisioning rates in explaining offspring growth performance.

Maternal size influenced pup growth rate only in 1998, suggesting that larger (and probably older) females were able to obtain food more efficiently than smaller females. Thus, during 1998 larger females had a competitive advantage over smaller and younger mothers during periods of environmental stress. A similar relationship has been found for the sub-Antarctic fur seal Arctocephalus tropicalis at Amsterdam Island in periods of low food availability, when pup growth rates were positively related to maternal length (Georges \& Guinet 2000). Thus, it would appear that selective pressure might act on different phenotypic traits, such as body length, in relation to different environmental conditions. One could argue that experience rather than size is the important factor. However in a recent study of $A$. tropicalis, foraging success was correlated with size but not with age, larger individuals being able to provide their pups with greater quantities of milk. Thus, in fur seals, size seemingly contributes to maternal efficiency only when environmental conditions are poor (this study) and/or food resources are distant (Beauplet et al. 2004), while maternal size does not contribute to foraging efficiency in years of high food availability and/or when food resources are close to the colony (McCafferty et al. 1998, Guinet et al. 1999, this study). Georges \& Guinet (2000) argued that larger females are more able to exploit distant food resources because they can store more reserves and thus increase their residency time in areas of high prey density. However, at Kerguelen in 1998 despite the fact that seals had greater difficulty in provisioning their pups, AFS females stayed closer to the colony than in 1999 and 2000 , suggesting that this location was the area of greatest prey density (if not accessibility, because of greater depths) within their foraging range. We can hypothesise that under these conditions, because of their greater aerobic dive limit (ADL), larger females were better able to access these deeper food resources than smaller females. However in 1999 and 2000, when food availably and accessibility were higher, female size was not a contributing factor to foraging success.

Conversely, the level of inter-individual variability in diving strategies was reduced under conditions of lower prey availability. Seals in 1998 tended to remain closer to the colony than in other years, diving to greater mean depths (Lea et al. 2002c) over the plateau edge and feeding more on neritic icefish. It is possible that the degree of intraspecific competition resulting from the majority of seals foraging in one region 
(Bonadonna et al. 2000), was minimised by differences in an individual's diving capabilities. Individual variability in the competitive ability of foraging animals arises from variation in foraging efficiency and susceptibility to interference (Caldow et al. 1999). In our study, in years of reduced prey availability there were advantages, or perhaps reduced costs, associated with remaining closer to the colony, even at the risk of higher levels of intraspecific competition. The local availability of prey undoubtedly influenced the 3 dimensional distribution of the seals' foraging effort, and was higher to the NE of the colony in 1998 (Guinet et al. 2001). As prey were located deeper in the water column in that year, travelling to the prey became a significant component of the diving time budget (Boyd 1997), effectively reducing the amount of time available for prey handling. The poor body condition of females during 1998 may also have contributed to reduced movements. Increased levels of surface swimming, as indicated by greater distances travelled from the colony in 2000, are thought to incur higher energetic costs (Arnould et al. 1996, Costa et al. 2000) and may not have been sustainable in 1998. Better body condition and generally higher levels of prey abundance and accessibility at shallower depths in 2000 may have allowed females to reduce the costs associated with competition from other seals by foraging further afield. Alternatively, we can hypothesise that this location was one of the few within the fur seals' foraging range where prey were accessible and sufficiently abundant that year.

Females had to dive deeper to get access to their prey resources in 1998 than in 1999 and 2000. Females in this year also concentrated their diving activity at night, and the dive profiles of female AFS were typical of seals feeding on a vertically migrating prey source such as myctophids (see Lea et al. 2002c). In 1998, the females restricted their periods of diving activity, spending $97 \%$ of their time diving at night and generally resting during the day (Bonadonna et al. 2000). As female AFS were diving deeper in 1998, their TSD decreased because they were unable to increase their diving rate (i.e. their at-sea energy expenditure). Not surprisingly, hourly dive frequency was lowest in this year. However the strong, predictive relationship between dive frequency and absolute pup mass gain suggests that dive rate appears to be a better indicator of the diving effort and foraging efficiency of AFS females at Kerguelen than proportional TSD.

\section{Implications of sustained climatic anomalies}

Climatic seasonality has been shown to be the ultimate determinant of the precisely timed lifecycle of sub-polar northern fur seals (Trites \& Antonelis 1994). Climatic anomalies, affecting food availability (Loeb et al. 1997, Waluda et al. 2004) and the nutritional status of lactating females (Lunn \& Boyd 1993a, this study), can in turn influence the implantation and/or growth rate of foetuses (Boyd \& McCann 1989, Trites 1991) and negatively affect neonatal survival (Trillmich \& Dellinger 1991, Boyd et al. 1994, Soto et al. 2004).

The increasing incidence and scale of warm anomalous conditions in the southern Indian Ocean (Weimerskirch et al. 2003) is demonstrated for the region prospected by the AFS in Fig. 8. In the $6 \mathrm{yr}$ leading up to the 1997/98 ENSO event, conditions within the current foraging zone of AFS were cooler than average, while in all 6 yr from 1997 to 2002, SSTs NE of the Kerguelen Archipelago were anomalously warm. Inchausti et al. (2003) suggested that breeding performance of seabirds in this region may be decreased by a southward shift in the Polar Front caused by oceanic warming. Implications may be more pronounced for less mobile central place foragers such as AFS. Recent analyses have shown that anomalously warm SSTs in February or March in the year prior to pupping are associated with decreased breeding success of AFS the following year at South Georgia (Leaper et al. 2004) and Macquarie Islands (S. Goldsworthy unpubl. data) respectively. Whilst the time series is too short to evaluate similar relationships at Kerguelen, significant interannual differences in maternal and pup body condition were shown to occur, with concurrent changes in oceanic conditions and prey availability. Long-term monitoring of AFS and breeding success and foraging behaviour at Kerguelen, particularly during winter months, would better elucidate such relationships. The close proximity of Kerguelen to the PF provides a rare opportunity in the SO to evaluate the effects of climatic anomalies, and their increasing incidence, on the productivity of the $\mathrm{PF}$ and related trends in marine predator populations.

Finally, the body condition of female AFS at Kerguelen, even during productive years such as 2000, was always lower that of their South Georgian counterparts under poor conditions (McCafferty et al. 1998). The superior size and condition of females at South Georgia under all conditions suggests that localised and or advected oceanic conditions (see Thorpe et al. 2004) and prey availability exert considerable influence on the life history of AFS. The behaviour of myctophidfeeding AFS in the southern Indian Ocean differs markedly from that of the primary krill feeding population in the southern Atlantic Ocean. AFS from Kerguelen displayed the highest absolute and mean dive depths and trip durations of any breeding AFS females to date during periods of environmental variability associated with climatic anomalies. Thus, while the 
response of 1 AFS population to localised conditions and/or sustained climatic change may not necessarily be used to predict the behaviour of others, environmental variability within the foraging zones of lactating AFS clearly affects breeding success throughout their circumpolar range.

Acknowledgements. The Insitut Paul Emil Victor (IPEV), the Terres Australes et Antarctiques Françaises (TAAF), the Australian Antarctic Scientific Advisory Committee (ASAC) and the Sea World Research and Rescue Foundation Inc. (Australia) provided funding. M.A.L. was supported by an Australian Government Postgraduate Award (1997 to 2001). All research was conducted under the ethics and scientific approval of IPEV. We particularly thank S. Goldsworthy, Professor M. Bryden, S. Thalmann, S. Samtmann, M. Koudil, F. Bonadonna, A. Céalis, F. Champly and expeditioners to Kerguelen in 1998 to 2000 for their assistance. Bristol-Myers Squibb (Australia) kindly donated Clairol Bleaching products, and 2 anonymous reviewers provided helpful comments.

\section{LITERATURE CITED}

Abbott MR, Richman JG, Letelier RM, Bartlett JS (2000) The spring bloom in the Antarctic Polar Frontal Zone as observed from a mesoscale array of bio-optical sensors. Deep-Sea Res II 47:3285-3314

Abbott MR, Richman JG, Letelier RM, Bartlett JS (2000) The spring bloom in the Antarctic Polar Frontal Zone as observed from a mesoscale array of bio-optical sensors. Deep-Sea Res II 47:3285-3314

Arnould JPY, Boyd IL, Speakman JR (1996) The relationship between foraging behaviour and energy expenditure in Antarctic fur seals. J Zool 239:769-782

Beauplet G, Dubroca L, Guinet C, Cherel Y, Dabin W, Gagne C, Hindell M (2004) Foraging ecology of subantarctic fur seals (Arctocephalus tropicalis) breeding on Amsterdam Island: seasonal changes in relation to maternal characteristics and pup growth. Mar Ecol Prog Ser 273: 211-225

Belkin IM, Gordon AL (1996) Southern Ocean fronts from the Greenwich meridian to Tasmania. J Geophys Res 101: 3675-3696

Blain S, Tréguer P, Belviso S, Bucciarelli and 8 others (2001) A biogeochemical study of the island mass effect in the context of the iron hypothesis: Kerguelen Islands, Southern Ocean. Deep-Sea Res I 48:163-187

Block BA, Keen JE, Castillo B, Dewar H, Freund EV, Marcinek DJ, Brill RW, Farwell C (1997) Environmental preferences of yellowfin tuna (Thunnus albacares) at the northern extent of its range. Mar Biol 130:119-132

Bonadonna F, Lea MA, Guinet C (2000) Foraging routes of Antarctic fur seals (Arctocephalus gazella) investigated by the concurrent use of satellite tracking and time-depth recorders. Polar Biol 23:149-159

Bonadonna F, Lea MA, Dehorter O, Guinet C (2001) Foraging ground fidelity and route-choice tactics of a marine predator: the Antarctic fur seal (Arctocephalus gazella). Mar Ecol Prog Ser 223:287-297

Bonner WN (1984) Lactation strategies in pinnipeds: problems for a marine mammalian group. Symp Zool Soc 51: 253-272

Boyd IL (1997) The behavioural and physiological ecology of diving. Trends Ecol Evol 12:213-217
Boyd IL (1999) Foraging and provisioning in Antarctic fur seals: interannual variability in time-energy budgets. Behav Ecol Sociobiol 10:198-208

Boyd IL (2000) State-dependent fertility in pinnipeds: contrasting capital and income breeders. Funct Ecol 14: 623-630

Boyd IL, McCann TS (1989) Pre-natal investment in reproduction by female Antarctic fur seals. Behav Ecol Sociobiol 24: 377-385

Boyd IL, Arnould JPY, Barton T, Croxall JP (1994) Foraging behaviour of Antarctic fur seals during periods of contrasting prey abundance. J Anim Ecol 63:703-713

Boyd IL, Croxall JP, Lunn NJ, Reid K (1995) Population demography of Antarctic fur seals: the costs of reproduction and implications for life-histories. J Anim Ecol 64:505-518

Bucciarelli E, Blain S, Tréguer P (2001) Iron and manganese in the wake of the Kerguelen Islands (Southern Ocean). Mar Chem 73:21-36

Caldow RWG, Goss-Custard JD, Stillman RA, Durrell SEA Le V. dit, Swinfen R, Bregnballe T (1999) Individual variation in the competitive ability of interference-prone foragers: the relative importance of foraging efficiency and susceptibility to interference. J Anim Ecol 68:869-878

Cherel Y, Guinet C, Tremblay Y (1997) Fish prey of Antarctic fur seals Arctocephalus gazella at Ile de Croy, Kerguelen. Polar Biol 17:87-90

Costa DP, Antonelis GA, DeLong RL (1991) Effects of El Niño on the foraging energetics of the California sea lion. In: Trillmich F, Ono KA (eds) Pinnipeds and El Niño-responses to environmental stress. Springer-Verlag, Berlin, p 156-165

Costa DP, Goebel ME, Sterling JT (2000) Foraging energetics and diving behaviour of the Antarctic fur seal Arctocephalus gazella, at Cape Shireff, Livingston Island. In: Davidson W, Howard-Williams C, Broady P (eds) Antarctic ecosystems: models for wider ecological understanding. New Zealand Natural Sciences, Christchurch, p 77-84

Duhamel G, Koubbi P, Ravier C (2000) Day and night mesopelagic fish assemblages off the Kerguelen Islands (Southern Ocean). Polar Biol 23:106-112

Fiedler PC (2002) Environmental change in the eastern tropical Pacific Ocean: a review of ENSO and decadal variability. Mar Ecol Prog Ser 244:265-283

Field I, Hindell M, Slip DJ, Michael K (2001) Foraging strategies of southern elephant seals (Mirounga leonina) in relation to frontal zones and water masses. Antarct Sci 13: 371-379

Francis J, Boness D, Ochoa-Acuna H (1998) A protracted foraging and attendance cycle in female Juan Fernandez fur seals. Mar Mamm Sci 14:552-574

Gentry RL, Kooyman GL (eds) (1986) Fur seals: maternal strategies on land and at sea. Princeton University Press, Princeton, NJ

Georges JY, Guinet C (2000) Maternal care in the subantarctic fur seals on Amsterdam Island. Ecology 81:295-308

Georges JY, Bonadonna F, Guinet C (2000) Foraging habitat and diving activity of lactating subantarctic fur seals in relation to sea-surface temperatures at Amsterdam Island. Mar Ecol Prog Ser 196:279-290

Goldsworthy SD (1999) Maternal attendance behaviour of sympatrically breeding Antarctic and subantarctic fur seals, Arctocephalus spp., at Macquarie Island. Polar Biol 21:316-325

Grotzner A, Latif M, Dommenget D (2000) Atmospheric response to sea surface temperature anomalies during El Niño 1997/98 as simulated by ECHAM4. Q J R Meteorol Soc B 126:2175-2198 
Guinet C, Cherel Y, Ridoux V, Jouventin P (1996) Consumption of marine resources by seabirds and seals in Crozet and Kerguelen waters: changes in relation to consumer biomass 1962-85. Antarct Sci 8:23-30

Guinet C, Jouventin P, Georges JY (1994) Long term population changes of fur seals Arctocephalus gazella and Arctocephalus tropicalis on subantarctic (Crozet) and subtropical (St Paul and Amsterdam) islands and their possible relationship to El Niño Southern Oscillation. Antarct Sci 6: 473-478

Guinet CG, Chastel O, Koudil M, Durbec JP, Jouventin P (1998a) Effects of warm sea-surface temperature anomalies on the blue petrel at the Kerguelen Islands. Proc R Soc Lond B 265:1001-1006

Guinet C, Roux JP, Bonnet M, Mison V (1998b) Effect of body size, body mass, and body condition on reproduction of female South African fur seals (Arctocephalus pusillus) in Namibia. Can J Zool 76:1418-1424

Guinet C, Goldsworthy SD, Robinson S (1999) Sex differences in mass loss rate and growth efficiency in Antarctic fur seal (Arctocephalus gazella) pups at Macquarie Island. Behav Ecol Sociobiol 46:157-163

Guinet C, Lea MA, Goldsworthy SD (2000) Mass change in Antarctic fur seal (Arctocephalus gazella) pups in relation to maternal characteristics at the Kerguelen Islands. Can J Zool 78:476-483

Guinet C, Dubroca L, Lea MA, Goldsworthy SD, Cherel Y, Duhamel G, Bonadonna F, Donnay JP (2001) Spatial distribution of foraging in female Antarctic fur seals Arctocephalus gazella in relation to oceanographic variables: a scale dependent approach using geographic information systems. Mar Ecol Prog Ser 219:251-264

Hare SR, Mantua NJ (2000) Empirical evidence for North Pacific regime shifts in 1977 and 1989. Prog Oceanogr 47: 103-146

Hofer H, East ML (1993) The commuting system of Serengeti spotted hyaenas: how a predator copes with migratory prey. III. Attendance and maternal care. Anim Behav 46: 575-589

Houston AL, Carbone C (1992) The optimal allocation of time during the dive cycle. Behav Ecol Sociobiol 3:155-165

Inchausti P, Guinet C, Koudil M, Durbec JP, Barbraud C, Weimerskirch H, Cherel Y, Jouventin P (2003) Interannual variability in breeding performance of seabirds in relation to oceanographic anomalies that affect the Crozet and Kerguelen sectors of the Southern Ocean. J Avian Biol 34: 170-176

Klages NTW, Bester MN (1998) Fish prey of fur seals Arctocephalus spp. at subantarctic Marion Island. Mar Biol 131: 559-566

Lea MA, Dubroca L (2003) Fine-scale linkages between diving behaviour of Antarctic fur seals and oceanographic features in the southern Indian Ocean. ICES J Mar Sci 60: $1-13$

Lea MA, Bonadonna F, Hindell M, Goldsworthy SD, Guinet C (2002a) Drinking behaviour and water turnover rates of Antarctic fur seal pups: implications for the estimation of milk intake by isotopic dilution. Comp Biochem Physiol A 132:321-331

Lea MA, Cherel Y, Guinet C, Nichols PD (2002b) Antarctic fur seals foraging in the Polar Frontal Zone: interannual shifts in diet as shown from faecal and fatty acid analyses. Mar Ecol Prog Ser 245:281-297

Lea MA, Hindell M, Guinet C, Goldsworthy SD (2002c) Variability in the diving activity of Antarctic fur seals, Arctocephalus gazella, at Iles Kerguelen. Polar Biol 25: 269-279
Lea MA, Cherel Y, Guinet C, Nichols PD (2003) ErratumAntarctic fur seals foraging in the Polar Frontal Zone: interannual shifts in diet as shown by faecal and fatty acid analyses. Mar Ecol Prog Ser 253:310

Leaper R, Cooke J, Trathan P, Reid K, Rowntree V, Payne R (2004) The influence of environmental variables on southern right whale (Eubalaena australis) population dynamics in the southwest Atlantic. Rep Int Whal Comm SC/56/SOS6:1-9

Lee PC, Majluf P, Gordon IJ (1991) Growth, weaning and maternal investment from a comparative perspective. J Zool 225:99-114

Loeb V, Siegel V, Holm-Hansen O, Hewitt R, Fraser W, Trivelpiece W, Trivelpiece S (1997) Effects of sea-ice extent and krill or salp dominance on the Antarctic food web. Nature 387:897-900

Lunn NJ, Boyd IL (1993a) Effects of maternal age and condition on parturition and the perinatal period of Antarctic fur seals. J Zool 229:55-67

Lunn NJ, Boyd IL (1993b) Influence on maternal characteristics and environmental variation on reproduction in Antarctic fur seals. Symp Zool Soc 66:115-129

McCafferty DJ, Boyd IL, Walker TR, Taylor RI (1998) Foraging responses of Antarctic fur seals to changes in the marine environment. Mar Ecol Prog Ser 166:285-299

Moore JK, Abbott MR (2000) Phytoplankton chlorophyll distributions and primary production in the Southern Ocean. J Geophys Res 105:28709-28722

Moore JK, Abbott MR, Richman JG (1999) Location and dynamics of the Antarctic Polar Front from satellite sea surface temperature data. J Geophys Res 104:3059-3073

Mori Y, Boyd IL (2004) The behavioural basis for nonlinear functional responses and optimal foraging in Antarctic fur seals. Ecology 85:398-410

Nel DC, Lutjeharms JRE, Pakhomov EA, Ansorge IJ, Ryan PG, Klages NTW (2001) Exploitation of mesoscale oceanographic features by grey-headed albatross Thalassarche chrysostoma in the Southern Indian Ocean. Mar Ecol Prog Ser 217:15-26

Oftedal OT (1984) Milk composition, milk yield and energy output at peak lactation: a comparative review. Symp Zool Soc 51:33-85

Orians GH, Pearson NE (1979) On the theory of central place foraging. In: Horn DJ, Stairs ET, Mitchell RT (eds) Analysis of ecological system. Ohio State University Press, Columbus, OH, p 155-177

Orsi AH, Whitworth T III, Nowlin WD Jr (1995) On the meridional extent and fronts of the Antarctic Circumpolar Current. Deep-Sea Res I 42:641-673

Park YH, Charriaud E, Ruiz Pino D, Jéandel C (1998) Seasonal and interannual variability of the mixed layer properties and steric height at station KERFIX, south west of Kerguelen. J Mar Syst 17:571-586

Pomeroy PP, Fedak M, Rothery P, Anderson S (1999) Consequences of maternal size for reproductive expenditure and pupping success of grey seals at North Rona, Scotland. J Anim Ecol 68:235-253

Post E, Stenseth NC (1999) Climatic variability, plant phenology, and northern ungulates. Ecology 80:1322-1339

Reynolds RW, Smith TM (1994) Improved global sea surface temperature analyses. J Climatol 7:929-948

Soto KH, Trites AW, Arias-Schreiber M (2004) The effects of prey availability on pup mortality and the timing of birth of South American sea lions (Otaria flavescens) in Peru. J Zool 264:419-428

Sparrow MD, Heywood KJ (1996) Current structure of the south Indian Ocean. J Geophys Res 101:6377-6391 
Springer AM, Piatt JF, van Vliet G (1996) Sea birds as proxies of marine habitats and food webs in the western Aleutian Arc. Fish Oceanogr 5:45-55

Stearns SC (1992) The evolution of life histories. Oxford University Press, New York

Thorpe SE, Heywood KE, Stevens DP, Brandon MA (2004) Tracking passive drifters in a high resolution ocean model: implications for interannual varaibility of larval krill transport to South Georgia. Deep-Sea Res I 51:909-920

Trillmich F, Dellinger T (1991) The effects of El Niño on Galapagos pinnipeds. In: Trillmich F, Ono KA (eds) Pinnipeds and El Niño - responses to environmental stress. SpringerVerlag, Berlin, p 66-74

Trillmich F, Lechner E (1986) Milk of the Galapagos fur seal and sea lion, with a comparison of the milk of eared seals (Otariidae). J Zool 209:271-277

Trites AW (1991) Fetal growth of northern fur seals: life-history strategy and sources of variation. Can J Zool 69:2608-2617

Editorial responsibility: Howard I. Browman (Associate Editor-in-Chief), Storebø, Norway
Trites AW, Antonelis GA (1994) The influence of climatic seasonality on the life cycle of the Pribilof northern fur seal. Mar Mamm Sci 10:311-324

Tynan CT (1998) Ecological importance of the southern boundary of the Antarctic circumpolar wave. Nature 392: 708-710

Waluda CM, Trathan PN, Rodhouse PG (2004) Synchronicity in southern hemisphere squid stocks and the influence of the Southern Oscillation and Trans Polar Index. Fish Oceanogr 13:255-266

Weimerskirch H, Barbraud C, Lys P (2000) Sex differences in parental investment and chick growth in wandering albatrosses: fitness consequences. Ecology 81:309-318

Weimerskirch H, Inchausti P, Guinet C, Barbraud C (2003) Trends in bird and seal populations as indicators of a system shift in the Southern Ocean. Antarct Sci 15:249-256

Williams RG, Follows MJ (1998) Eddies make ocean deserts bloom. Nature 394:228-229

Submitted: April 20, 2005; Accepted: August 25, 2005 Proofs received from author(s): February 2, 2006 